\title{
Testing of Alternative Abrasives for Water-Jet Cutting at C Tank Farm
}

\author{
EJ Krogstad
}

August 2013

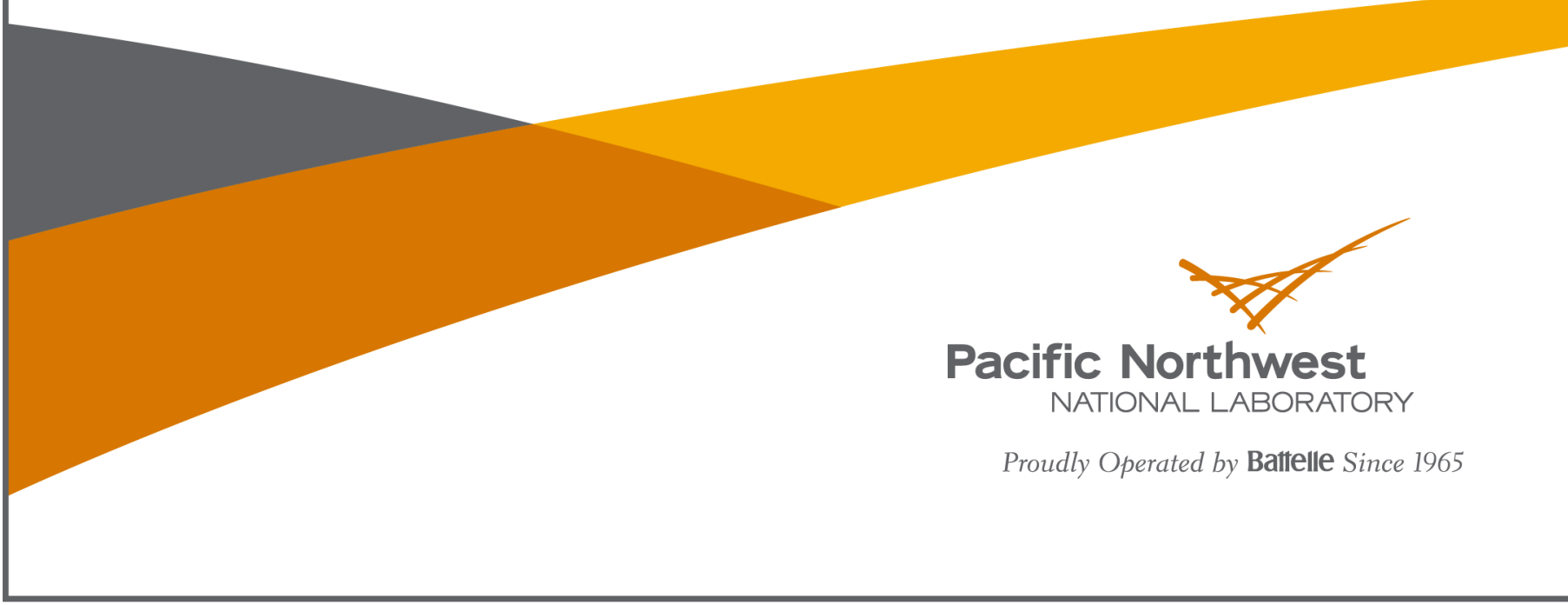




\title{
DISCLAIMER
}

This report was prepared as an account of work sponsored by an agency of the United States Government. Neither the United States Government nor any agency thereof, nor Battelle Memorial Institute, nor any of their employees, makes any warranty, express or implied, or assumes any legal liability or responsibility for the accuracy, completeness, or usefulness of any information, apparatus, product, or process disclosed, or represents that its use would not infringe privately owned rights. Reference herein to any specific commercial product, process, or service by trade name, trademark, manufacturer, or otherwise does not necessarily constitute or imply its endorsement, recommendation, or favoring by the United States Government or any agency thereof, or Battelle Memorial Institute. The views and opinions of authors expressed herein do not necessarily state or reflect those of the United States Government or any agency thereof.

\author{
PACIFIC NORTHWEST NATIONAL LABORATORY \\ operated by \\ BATTELLE \\ for the \\ UNITED STATES DEPARTMENT OF ENERGY \\ under Contract DE-AC05-76RL01830
}

Printed in the United States of America
Available to DOE and DOE contractors from the Office of Scientific and Technical Information, P.O. Box 62, Oak Ridge, TN 37831-0062; ph: (865) 576-8401 fax: $(865) 576-5728$
email: reports $a$ adonis.osti.gov
Available to the public from the National Technical Information Service 5301 Shawnee Rd., Alexandria, VA 22312 ph: (800) 553-NTIS (6847) email: orders@ntis.gov <http://www.ntis.gov/about/form.aspx> Online ordering: http://www.ntis.gov




\section{Testing of Alternative Abrasives for Water-Jet Cutting at C Tank Farm}

EJ Krogstad

August 2013

Prepared for

the U.S. Department of Energy

under Contract DE-AC05-76RL01830

Pacific Northwest National Laboratory

Richland, Washington 99352 



\section{Summary}

Legacy waste from defense-related activities at the Hanford Site has predominantly been stored in underground tanks, some of which have leaked; others may be at risk to do so. The U.S. Department of Energy's goal is to empty the tanks and transform their contents into more stable waste forms. To do so requires breaking up, and creating a slurry from, solid wastes in the bottoms of the tanks. A technology developed for this purpose is the Mobile Arm Retrieval System. This system is being used at some of the older single shell tanks at $\mathrm{C}$ tank farm. As originally planned, access ports for the Mobile Arm Retrieval System were to be cut using a high- pressure water-jet cutter. However, water alone was found to be insufficient to allow effective cutting of the steel-reinforced tank lids, especially when cutting the steel reinforcing bar ("rebar"). The abrasive added in cutting the hole in Tank C-107 was garnet, a complex natural aluminosilicate. The hardness of garnet (Mohs hardness ranging from $\mathrm{H} 6.5$ to 7.5) exceeds that of solids currently in the tanks, and was regarded to be a threat to Hanford Waste Treatment and Immobilization Plant systems. Olivine, an iron-magnesium silicate that is nearly as hard as garnet (H 6.5 to 7), has been proposed as an alternative to garnet.

Pacific Northwest National Laboratory proposed to test pyrite $\left(\mathrm{FeS}_{2}\right)$, whose hardness is slightly less (H 6 to 6.5) for 1) cutting effectiveness, and 2) propensity to dissolve (or disintegrate by chemical reaction) in chemical conditions similar to those of tank waste solutions. Cutting experiments were conducted using an air abrader system and a National Institute of Standards and Technology Standard Reference Material (SRM 1767 Low Alloy Steel), which was used as a surrogate for rebar. The cutting efficacy of pyrite was compared with that of garnet and olivine in identical size fractions. Garnet was found to be most effective in removing steel from the target; olivine and pyrite were less effective, but about equal to each other.

The reactivity of pyrite, compared to olivine and garnet, was studied in high-pH, simulated tank waste solutions in a series of bench-top experiments. Variations in temperature, degree of agitation, grain size, exposure to air, and presence of nitrate and nitrite were also studied. Olivine and garnet showed no sign of dissolution or other reaction. Pyrite was shown to react with the fluids in even its coarsest variation $(150-1000 \mu \mathrm{m})$. Projected times to total dissolution for most experiments range from months to ca. 12 years, and the strongest control on reaction rate is the grain size. 



\section{Contents}

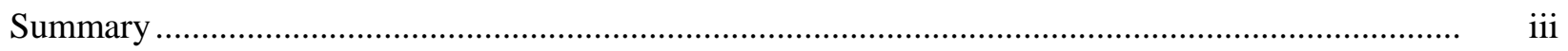

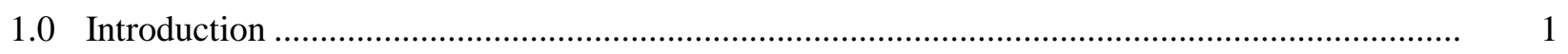

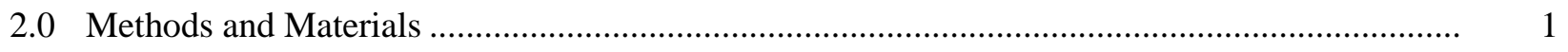

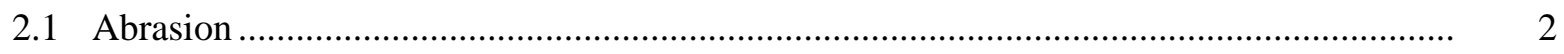

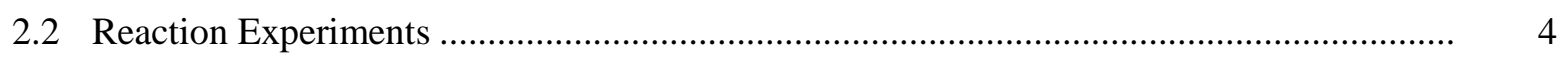

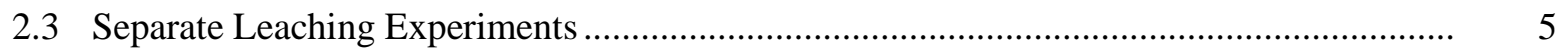

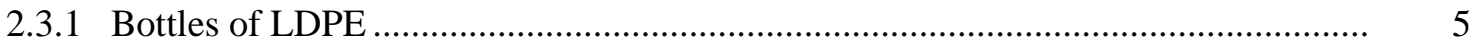

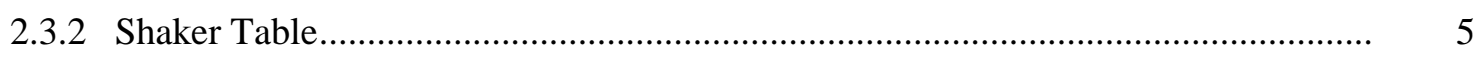

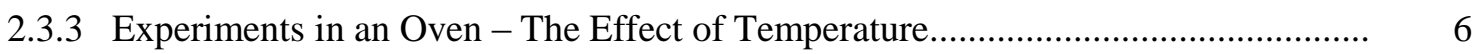

2.3.4 Experiments in a Fume Hood - The Effect of Exposure to Air .............................. 6

2.4 Chemical Analyses of Reaction Products in Solution ....................................................... 6

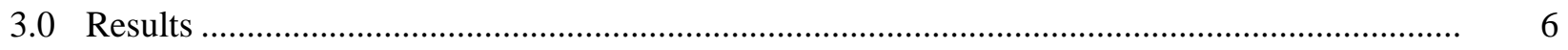

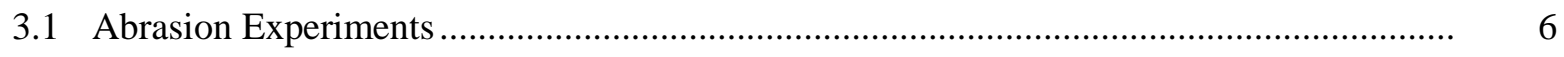

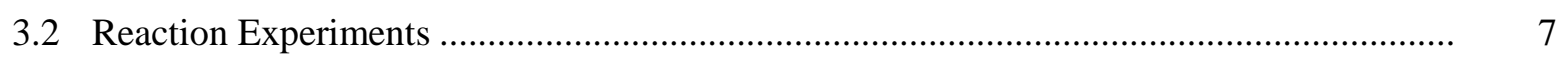

3.2.1 Garnet and Olivine Leaching Experiments ....................................................... 8

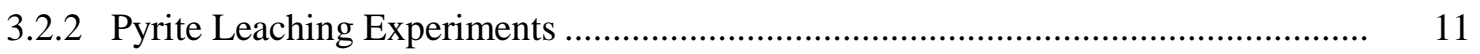

3.2.3 Projection to Reaction Completion .............................................................. 15

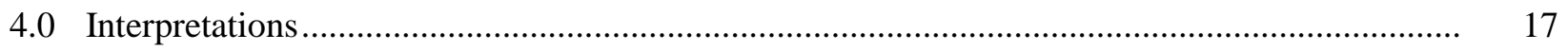

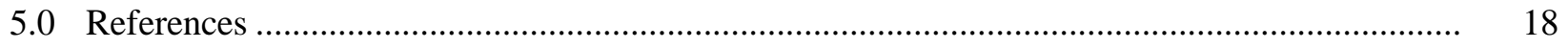

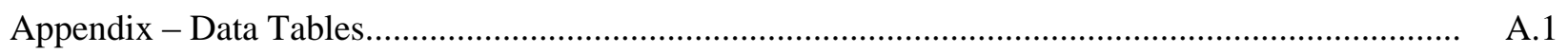




\section{Figures}

1. $\quad$ Miniaturized air abrader used in abrasion experiments ....................................................... 3

2. Sample disk of NIST 1767 (Low Alloy Steel) used as a cutting target ..................................... 3

3. Example of the leaching experiments .............................................................................. 5

4. Relative abrasion effectiveness of the three abrasives on a weight basis .................................. 7

5. Garnet, coarse fraction before leaching. .......................................................................... 8

6. Garnet, coarse fraction after leaching in Solution A ............................................................. 9

7. Garnet, coarse fraction after leaching in Solution B .............................................................

8. Olivine, coarse fraction before leaching .......................................................................... 10

9. Olivine, coarse fraction after leaching in Solution A........................................................... 10

10. Olivine, coarse fraction after leaching in Solution B ............................................................ 11

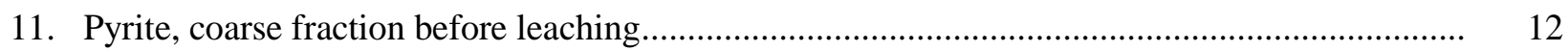

12. Pyrite, coarse fraction after leaching in Solution A ........................................................... 12

13. Pyrite, coarse fraction after leaching in Solution B. ............................................................. 13

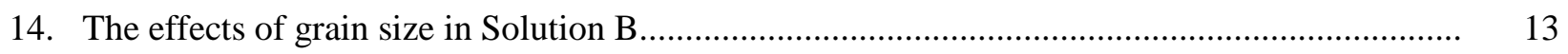

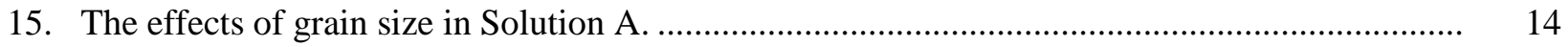

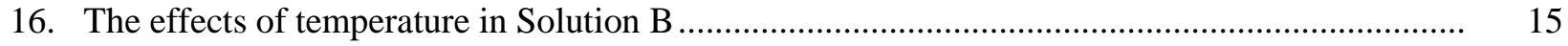

17. At $40^{\circ} \mathrm{C}$, as at $19^{\circ} \mathrm{C}$, the grain size has a large effect on reaction rate; the fine-grained experiments reacted more quickly than the coarse-grained experiments...................................... 15

18. In this experiment, $100 \mathrm{mg}$ of pyrite would be expected to completely dissolve in about 3 to

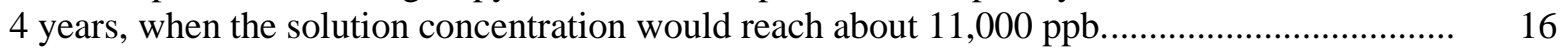

19. Coarse pyrite reaction in Solution B at $19^{\circ} \mathrm{C}$ was slower than in Solution A at $19^{\circ} \mathrm{C}$ on the shaker table

20. In this experiment, carried out in Solution B, dissolution of the pyrite is indicated to be slower than reactions in Solution A

\section{Tables}

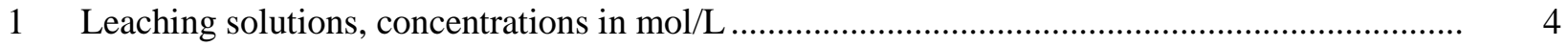

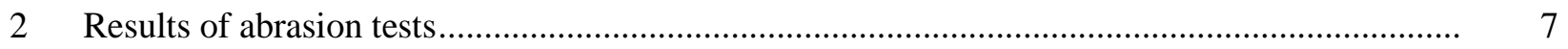

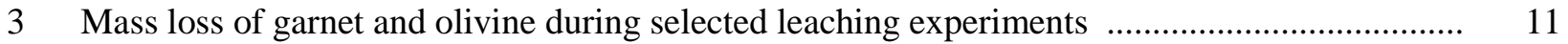




\subsection{Introduction}

Legacy waste from defense-related activities at the Hanford Site has predominantly been stored in underground tanks. Some of these tanks have leaked liquid and, in principle, all of them could eventually be at risk of doing so. Leakage can allow dangerous contaminants to seep into the ground, which could lead to groundwater contamination that might eventually discharge into the Columbia River. The U.S. Department of Energy's goal is to empty the tanks and transform their contents into more stable (glassified) waste forms.

Stabilization of the tank wastes will be done by vitrifying the solid wastes at the Waste Treatment Plant (WTP). To accomplish this, the solid wastes in the bottom of the tanks must first be broken up with a liquid to form a slurry to enable its transport to the WTP. A technology developed for this purpose is the Mobile Arm Retrieval System (MARS), which is being used at some of the older single-shell tanks at the C tank farm.

As initially planned, access ports for the MARS at C tank farm were to be cut using a high-pressure water-jet cutter. However, water alone proved to be insufficient to allow effective cutting of the steelreinforced concrete tank lid, especially when cutting the steel reinforcing bar ("rebar"). The rebar is expected to be similar in composition to American Society for Testing and Materials (ASTM) 607/A615 steel, which represents common reinforcing steel compositions. The abrasive added to the water jet for cutting the hole in Tank C-107 was garnet, a complex natural aluminosilicate. The hardness of garnet (Mohs hardness ranging from H 6.5 to 7.5; Klein and Hurlbut 1985) exceeds that of solids currently in the tanks, and was considered a threat to WTP systems. Olivine, an iron-magnesium silicate that is nearly as hard as garnet (H 6.5 to 7; Klein and Hurlbut 1985), has been proposed as an alternative abrasive.

Pacific Northwest National Laboratory (PNNL) proposed to test pyrite $\left(\mathrm{FeS}_{2}\right)$, whose hardness is slightly less (H 6 to 6.5; Klein and Hurlbut 1985) for its cutting effectiveness, and propensity to dissolve (or disintegrate by chemical reaction) in chemical conditions similar to those of tank waste solutions. This report describes the two experiments conducted to determine the cutting effectiveness of pyrite relative to the other abrasives and dissolution of pyrite relative to the other abrasives. Experimental methods, materials, results, and associated interpretations are presented in the ensuing sections; Appendix A contains related data tables.

\subsection{Methods and Materials}

Experiments were developed at PNNL to test two parameters: 1) whether pyrite would be able to cut the reinforcement bars in the tank lids, and 2) whether the pyrite would dissolve in the tank waste. The first test was accomplished using a miniaturized air abrader and the three candidate abrasives. The second series of tests used leaching or reaction experiments with the three abrasives and simulated tank fluids. 


\subsection{Abrasion Experiments}

A commercial air abrader (Figure 1) was purchased from Integral Systems, Inc. (X-blast Triple Tank) and modified for this experiment. The unit uses compressed nitrogen at 100 psi to drive abrasive through narrow nozzles at a target. Although the gas propellant pressures used (ca. $100 \mathrm{psi}$ ) were much lower than the water pressures used in actual water-jet cutting (ca. 50,000 psi), it was hypothesized that results from comparisons of air abrasion using the three candidate abrasives would provide indications of 1) the ability of pyrite to cut steel, and 2) an approximate relative cutting ability of the three abrasives.

Compressed nitrogen was used instead of normal air to obviate the spark and explosion hazard that might have accompanied pyrite-steel impacts. Use of pyrite as an abrasive in water streams would not constitute a spark or explosion threat.

A disk (Figure 2) of National Institute of Standards and Technology (NIST) SRM 767 (Low Alloy Steel) was obtained for use as a cutting target. It was chosen because of its compositional similarity to steel meeting the standards of American Society for Testing and Materials (ASTM) 607/A615 steel, which represents common reinforcing steel compositions.

The abrader was reconfigured to use a single grain size range $(106-125 \mu \mathrm{m})$, with the used abrasive collected on a filter by a vacuum line. The abrasion nozzle was oriented at a set angle (ca. $\left.30^{\circ}\right)$ to the upper surface of the steel disk. Abrasion was conducted for a set period of time, typically 1 to 3 minutes, producing a pit in the disk (Figure 2). The weight of the disk was compared to its preabrasion weight to determine the weight of the steel removed. The mass of abrasive used in the experiment was determined by the difference in the weight of material in the abrasive reservoir before and after the abrasion. 


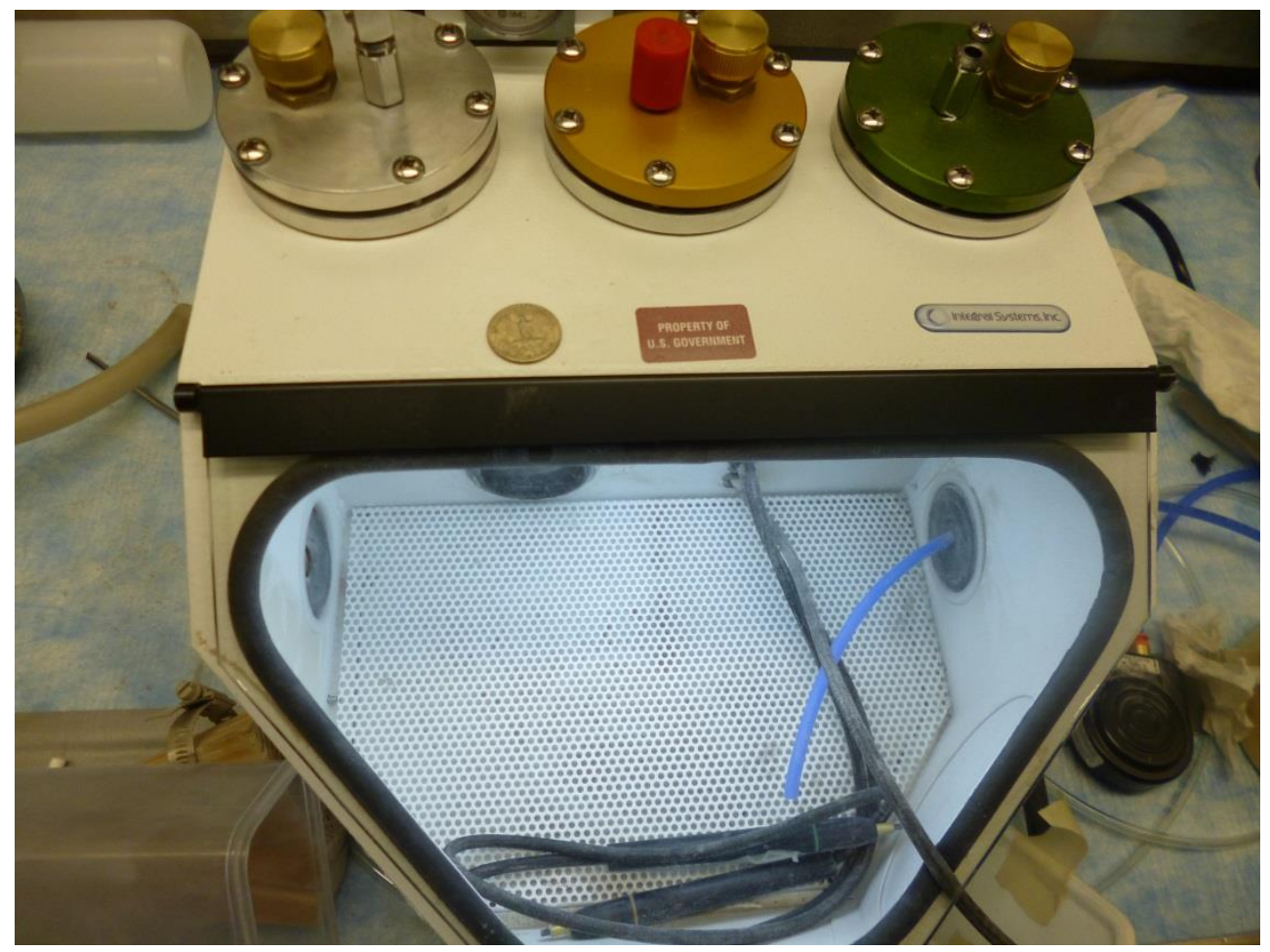

Figure 1. Miniaturized air abrader (Integral Systems Triple Blast) used in abrasion experiments. A U.S. quarter dollar coin atop the abrader provides scale.

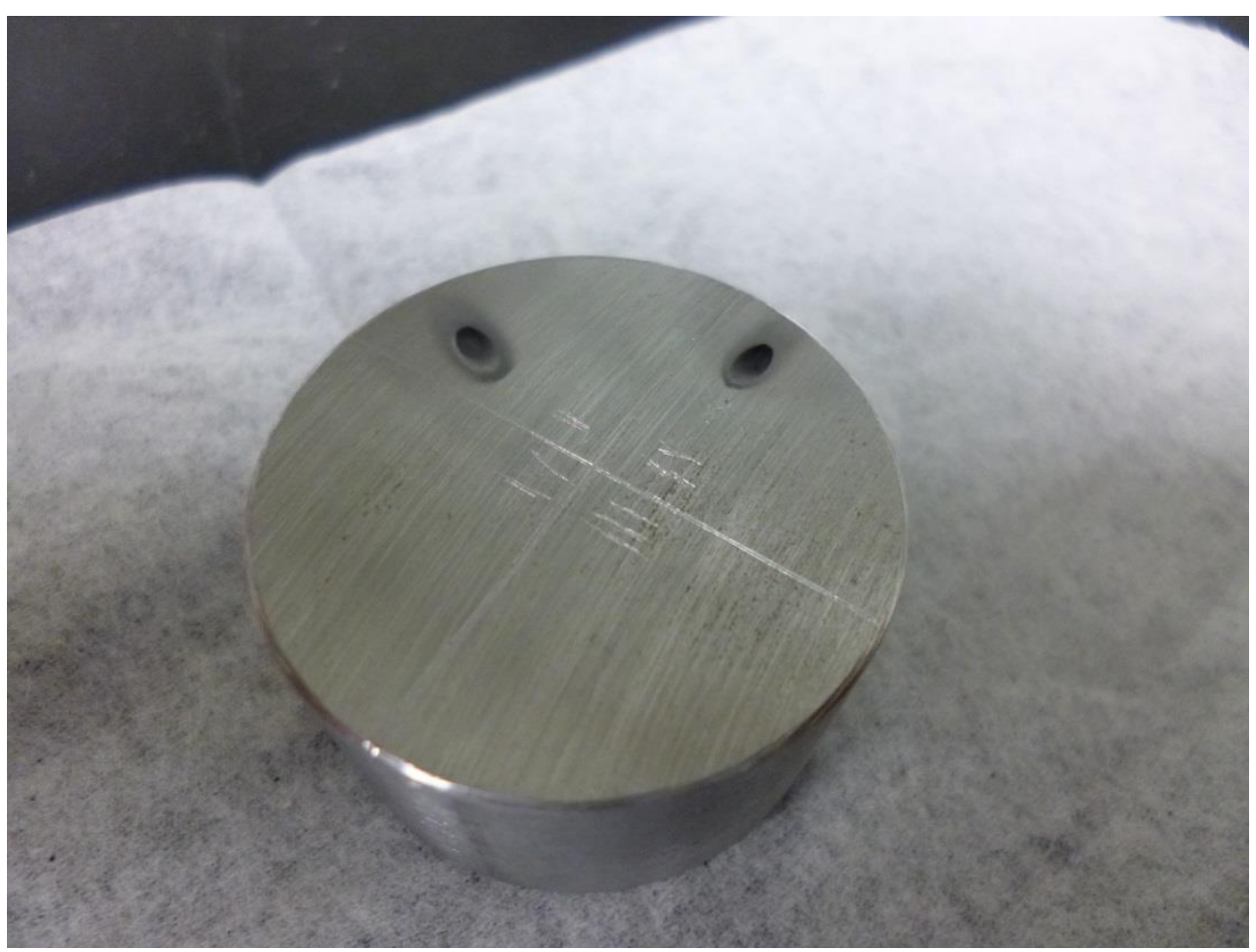

Figure 2. Sample disk of NIST 1767 (Low Alloy Steel) used as a cutting target. The top surface has been scribed into quadrants. Quadrant I (back) was abraded with garnet and $37.2 \mathrm{mg}$ were removed. Quadrant II (back right) was abraded with olivine and $29.1 \mathrm{mg}$ were removed. The disk is $34 \mathrm{~mm}$ in diameter and $19 \mathrm{~mm}$ thick. 


\subsection{Reaction Experiments}

Grain sizes for the three abrasives were chosen to represent 1) "out of the bag" size like that to be used in water-jet cutting $(150-1000 \mu \mathrm{m})$, and 2) a finer grain size $(<53 \mu \mathrm{m})$ to increase surface/volume effects. One-kilogram samples of garnet, olivine, and pyrite were obtained from Ward's Natural Science, Rochester, New York. The grain sizes were reduced by jaw crusher and disk mill (BICO, Burbank, California). Further grain size reduction (crushing in ring mill) was conducted, followed by sieving using ASTM traceable sieves to sieve sizes $<53 \mu \mathrm{m}, 53-150 \mu \mathrm{m}$ (with a subset of 106-125 $\mu \mathrm{m}$ ), 150-1000 $\mu \mathrm{m}$, and $>1000 \mu \mathrm{m}$. Fractions of two sizes ranges, $53 \mu \mathrm{m}$ and $150-1000 \mu \mathrm{m}$, were selected for leaching experiments. The choice of two fractions with such different grain sizes was initially made to enhance differences in leaching or reaction rates that might be a function of grain size.

Two solutions were prepared for the leach tests. One was made to $1 \mathrm{M} \mathrm{NaOH}$ by dissolving reagentgrade sodium hydroxide in high-purity (Milli-Q) water. This leaching solution is hereinafter referred to as Solution A. The second solution was made by dissolving reagent grade sodium hydroxide, sodium nitrate, sodium nitrite, sodium aluminate, sodium carbonate, and ferric chloride in Milli-Q purified water (Table 1). This solution is hereinafter referred to as Solution B.

Table 1. Leaching solutions, concentrations in $\mathrm{mol} / \mathrm{L}$.

\begin{tabular}{lcc}
\hline & Solution A & Solution B \\
\cline { 2 - 3 } \multicolumn{1}{c}{ Component } & Molarity & Molarity \\
\hline $\mathrm{NaOH}$ & 1.0 & 1.5 \\
$\mathrm{NaNO}_{3}$ & & 4 \\
$\mathrm{NaNO}_{2}$ & & 0.4 \\
$\mathrm{NaAlO}_{2}$ & & 0.5 \\
$\mathrm{Na}_{2} \mathrm{CO}_{3}$ & & 0.05 \\
$\mathrm{FeCl}_{3}$ & & 0.001 \\
\hline
\end{tabular}

Weighed amounts of each of the three abrasives in each size range were then placed in polypropylene bottles and one of two simulated tank solutions was added. Sampling of the solution in each bottle for dissolution products (i.e., constituent elements) of the abrasives over a period of several weeks was used as the method of determining reaction progress. This approach is based upon the assumption that these dissolution products will, once formed in solution, remain in solution and not re-precipitate. An example of this approach is to assume that sulfur as sulfate $\left(\mathrm{SO}_{4}{ }^{2-}\right)$ will be more likely to remain in solution from the decomposition of pyrite, but that ferrous iron will likely convert to ferric iron and re-precipitate as ferric oxides or hydroxides. Therefore, the dissolved sulfur was thought to be a better indicator of reaction progress in the dissolution of pyrite than iron. For the dissolution of garnet and olivine, silica and magnesium might be better indicators than, for example, iron or aluminum because of the relative insolubility of the latter two elements. 


\subsection{Separate Leaching Experiments}

Experiments involving the leaching of garnet were given the prefix $\mathrm{G}$, experiments involving the leaching of olivine were given the prefix of $\mathrm{O}$, and experiments involving the leaching of pyrite were given the prefix of P. One set of experiments was started in late July and August 2012. Another set was started on August 31, 2012, and run in parallel (Table A.1). In tables of leaching data, concentrations of leach products are tabulated versus days of reaction times so that results may be compared.

\subsubsection{Low-Density Polyethylene Bottles}

Standard screw-top $125-\mathrm{mL}$ low-density polyethylene bottles were used for the first series of experiments, and similar 60-mL bottles were used for the second series. To these were added a weighed amount of abrasive mineral, nominally $500 \mathrm{mg}$, but $100 \mathrm{mg}$ in P1. A leach solution of $50 \mathrm{~mL}$ was also added.

\subsubsection{Shaker Table}

A subset of the bottles was placed on a mechanical shaker table (Figure 3) to keep the solids and the reaction solutions well mixed. The bottles were kept capped at all times (except during sampling procedures) for safety reasons. The experiments were conducted on a laboratory bench top, at $19^{\circ} \mathrm{C}$.

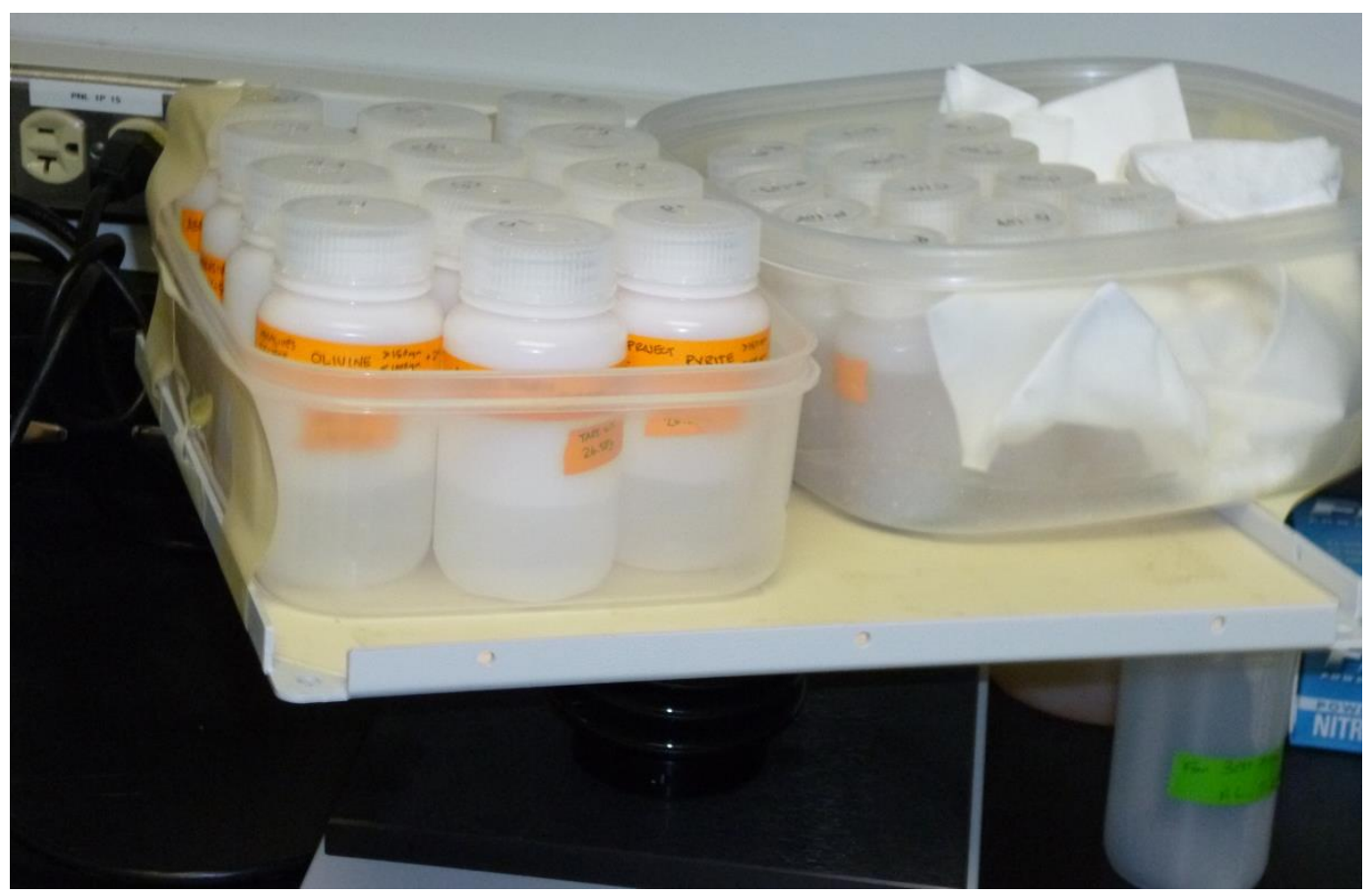

Figure 3. Example of the leaching experiments. The bottles including both Solution A and Solution B sit atop a reciprocal shaker at room temperature $\left(19^{\circ} \mathrm{C}\right)$. Each bottle contains $50 \mathrm{~mL}$ of leach solution, from with $0.5 \mathrm{~mL}$ was sampled intermittently for analysis. 


\subsubsection{Experiments in an Oven - The Effect of Temperature}

A laboratory oven set at $40^{\circ} \mathrm{C}$ was used to constrain the effect of temperature on reaction rates. This temperature was chosen because it was considered to be more pertinent to the actual temperature in some tanks than the laboratory temperature of $19^{\circ} \mathrm{C}$ at which other experiments were run. The bottles in the oven were kept capped at all times (except during sampling procedures) for safety reasons and to control the evaporation of the solutions.

\subsubsection{Experiments in a Fume Hood - The Effect of Exposure to Air}

A subset of the experiments was placed in a fume hood with appropriate secondary containment. These bottles were kept uncapped at all times. The experiments were conducted at ambient laboratory temperatures, which averaged $19^{\circ} \mathrm{C}$. Persistent evaporation required that volumes of the leaching solution be brought up to $50 \mathrm{~mL}$ at a rate of two to three times per week. This required large volumes of deionized water to be added to the bottles. Because the dissolved species are not considered volatile, this effect probably only resulted in temporary increases in solute concentrations. The exceptions to this were the experiments run in Solution B, in which a heavy crust formed on the bottom of the bottles.

\subsection{Chemical Analyses of Reaction Products in Solution}

Analysis of reaction products was conducted by sampling of $0.5 \mathrm{~mL}$ from each bottle at somewhat irregular intervals. The sample aliquots were diluted 100:1 in $2 \%$ nitric acid and submitted for analysis by inductively coupled optical emission spectrometer. These analyses were made using the Environmental Sciences Laboratory (ESL, Geosciences Group, Energy and Environment Division) standard quality assurance-quality control methods. The data were input into ESL's Laboratory Information Management System, and reviewed by an independent Geosciences Group scientist for conformity with ESL standards.

\subsection{Results}

The results derived from the abrasion and reaction experiments are described in the following sections.

\subsection{Abrasion (Cutting) Experiments}

The relative abrasivity of the three compared abrasives using the miniature air abrader was determined on NIST 1767, Low-Alloy Steel, because it was thought to best mimic the characteristics of the material used for rebar in the steel-reinforced concrete in the lids of the tanks (Table 2; Figure 4). Garnet proved to be the best abrader, removing the most steel for the amount of abrasive used. Olivine was less efficient, requiring about 1.4 times the amount of abrasive to remove the same amount of steel. Pyrite abrasion tests yielded variable results, from highly efficient to about as efficient as olivine. The sum of the pyrite abrasion tests provided an abrasion efficacy that was approximately equal to that of the olivine test. 
Table 2. Results of abrasion tests.

\begin{tabular}{lcccc}
\hline & $\begin{array}{c}\text { Mass Abrasive } \\
\text { Used }\end{array}$ & $\begin{array}{c}\text { Steel Target } \\
\text { Removed }\end{array}$ & $\begin{array}{c}\text { Steel } \\
\text { Removed/Abrasive } \\
\text { Used }\end{array}$ & $\begin{array}{c}\text { Abrasive } \\
\text { Used/Steel } \\
\text { Removed }\end{array}$ \\
\hline Units & $\mathrm{g}$ & $\mathrm{g}$ & $\mathrm{g} / \mathrm{g}$ & $\mathrm{g} / \mathrm{g}$ \\
\hline Garnet & 22.14 & 0.0372 & 0.00168 & 595 \\
Olivine & 24.10 & 0.0291 & 0.00121 & 826 \\
Pyrite 1 & 3.05 & 0.0068 & 0.0063 & 159 \\
Pyrite 2 & 11.66 & 0.0124 & 0.00106 & 943 \\
Pyrite 3 & 8.39 & 0.0095 & 0.00113 & 885 \\
Total pyrite tests & $\mathbf{2 2 . 0 8}$ & $\mathbf{0 . 0 2 8 7}$ & $\mathbf{0 . 0 0 1 3 0}$ & $\mathbf{7 6 9}$ \\
\hline
\end{tabular}

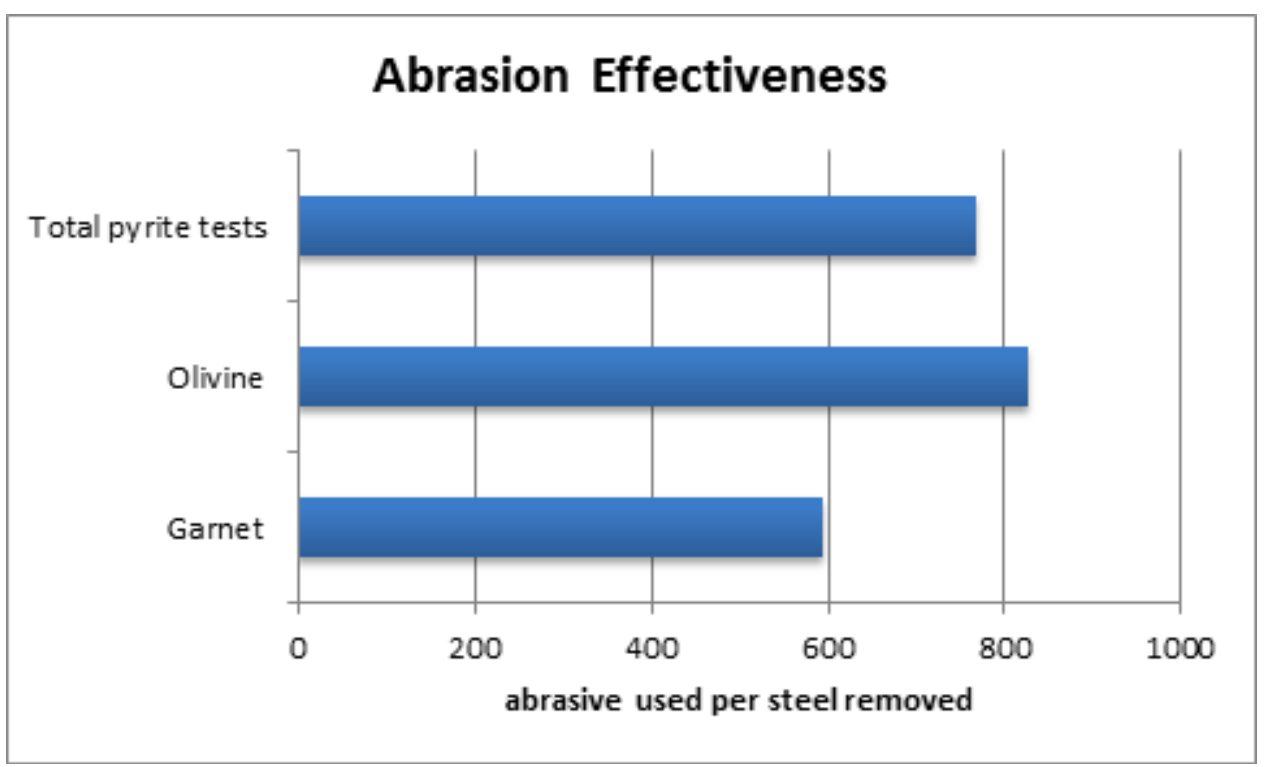

Figure 4. Relative abrasion effectiveness of the three abrasives on a weight basis. Note that garnet is the most effective abrasive, and that olivine is somewhat less effective at removing steel. The total steel removed by pyrite divided into the amount of pyrite used in the three tests is comparable to that for olivine and pyrite.

It should be noted that the results of this air abrasion test merely demonstrate that pyrite, like the other two abrasives, is capable of cutting the target steel disk. It should not be concluded from these results that quantitative estimates could be made of the amount of any particular abrasive that would need to be added to a high-pressure water-jet cutting apparatus to cut a particular amount of steel-reinforced concrete.

\subsection{Reaction Experiments}

The results of the reaction experiments are presented below first for garnet and olivine, then pyrite, followed by projections of reaction completion times. 


\subsubsection{Garnet and Olivine Leaching Experiments}

There was no obvious reaction in the garnet and olivine leaching experiments (Figure 5 through Figure 10), except for the minor Fe-oxide coatings in Figure 10. Furthermore, two each of the direct measurements of the mass loss from four of the garnet and olivine leaching experiments, (Table 3 O101, O109, G101, and G109) showed very little loss of mass. This mass loss could be due to loss of more soluble impurities in the minerals and not the olivine and garnet themselves. This is consistent with the elemental concentration data from the leaching experiment analyses that show little evidence for dissolution products appearing in solution (Table A.2). In fact, dissolution products $\mathrm{Mg}, \mathrm{Al}, \mathrm{Fe}$, and $\mathrm{Si}$, decrease with time, except for the experiments using Solution B, in which $\mathrm{Al}$ and Fe were introduced as a part of the leaching solution. Therefore, there is no evidence that reactions progressed during the experimental time period. These leaching experiments are not discussed further in this report.

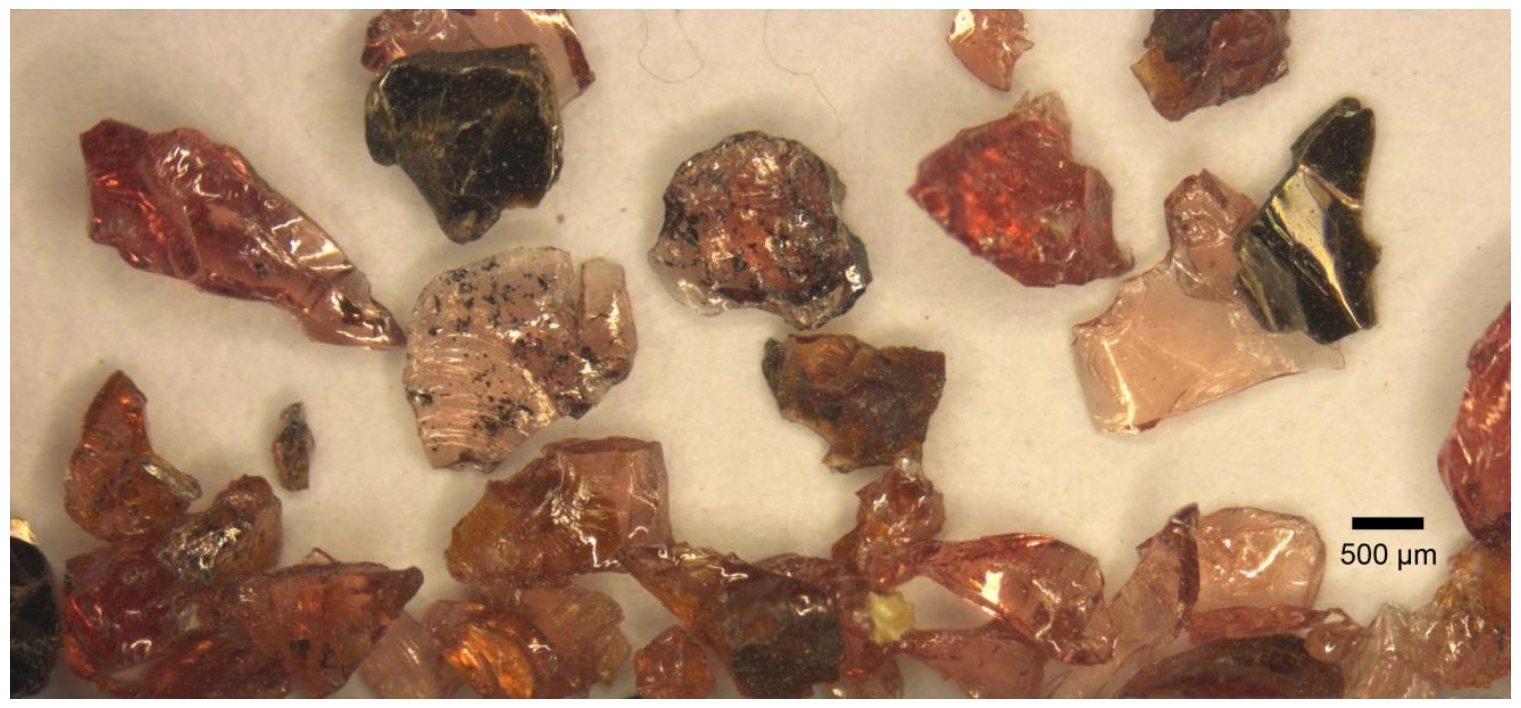

Figure 5. Garnet, coarse fraction $(150-1000 \mu \mathrm{m})$ before leaching. Sizes shown are not intended to be representative. This view shows conchoidally fractured garnet with flaky, dark biotite (mica) impurities. 


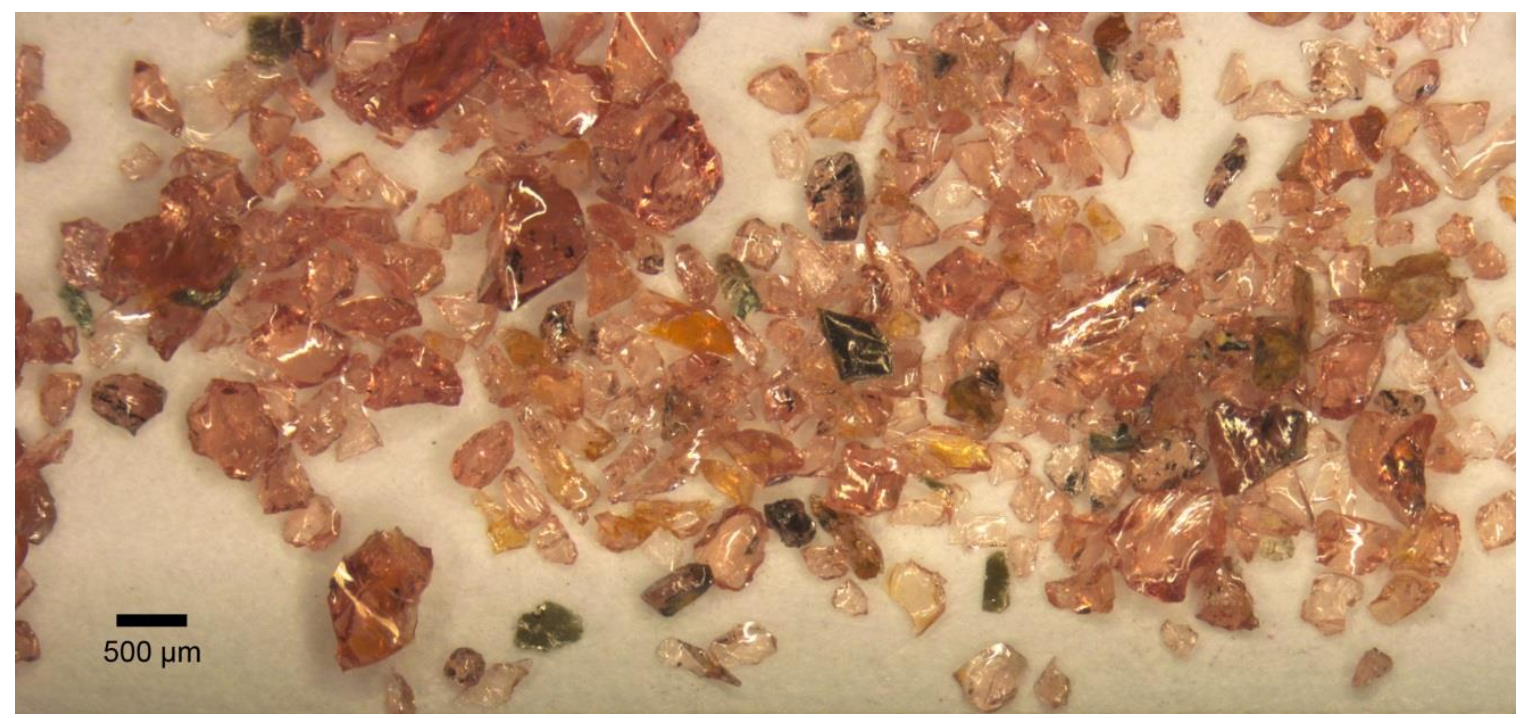

Figure 6. Garnet, coarse fraction (150-1000 $\mu \mathrm{m})$ after leaching in Solution A (Experiment G101). Sizes shown are not intended to be representative. This sample had an apparent loss over 109 days of $1.0 \%$ of its mass (Table 3), which may have been due to loss during recovery and filtering, or dissolution of mineral impurities.

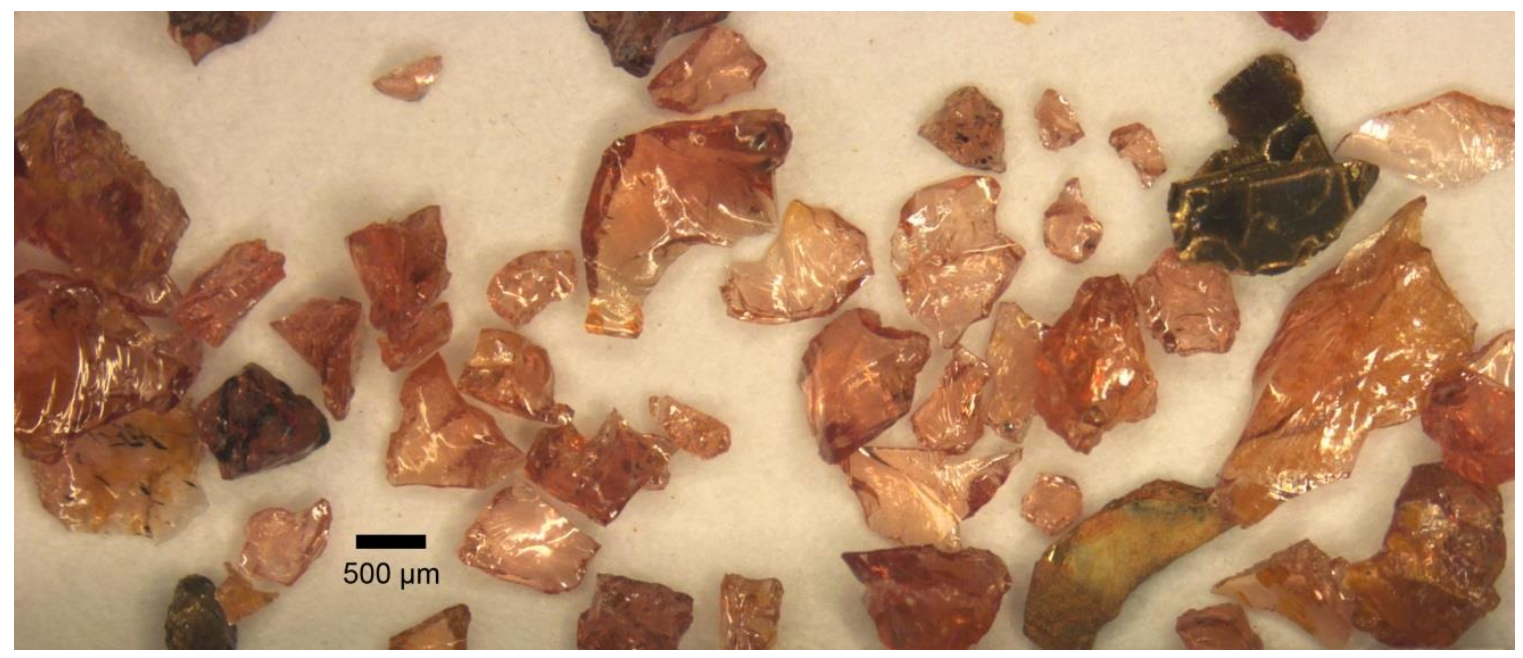

Figure 7. Garnet, coarse fraction (150-1000 $\mu \mathrm{m})$ after leaching in Solution B (Experiment G109). Sizes shown are not intended to be representative. This sample had an apparent loss over 109 days of $2.5 \%$ of its mass (Table 3 ), which may have been due to loss during recovery and filtering, or dissolution of mineral impurities. 


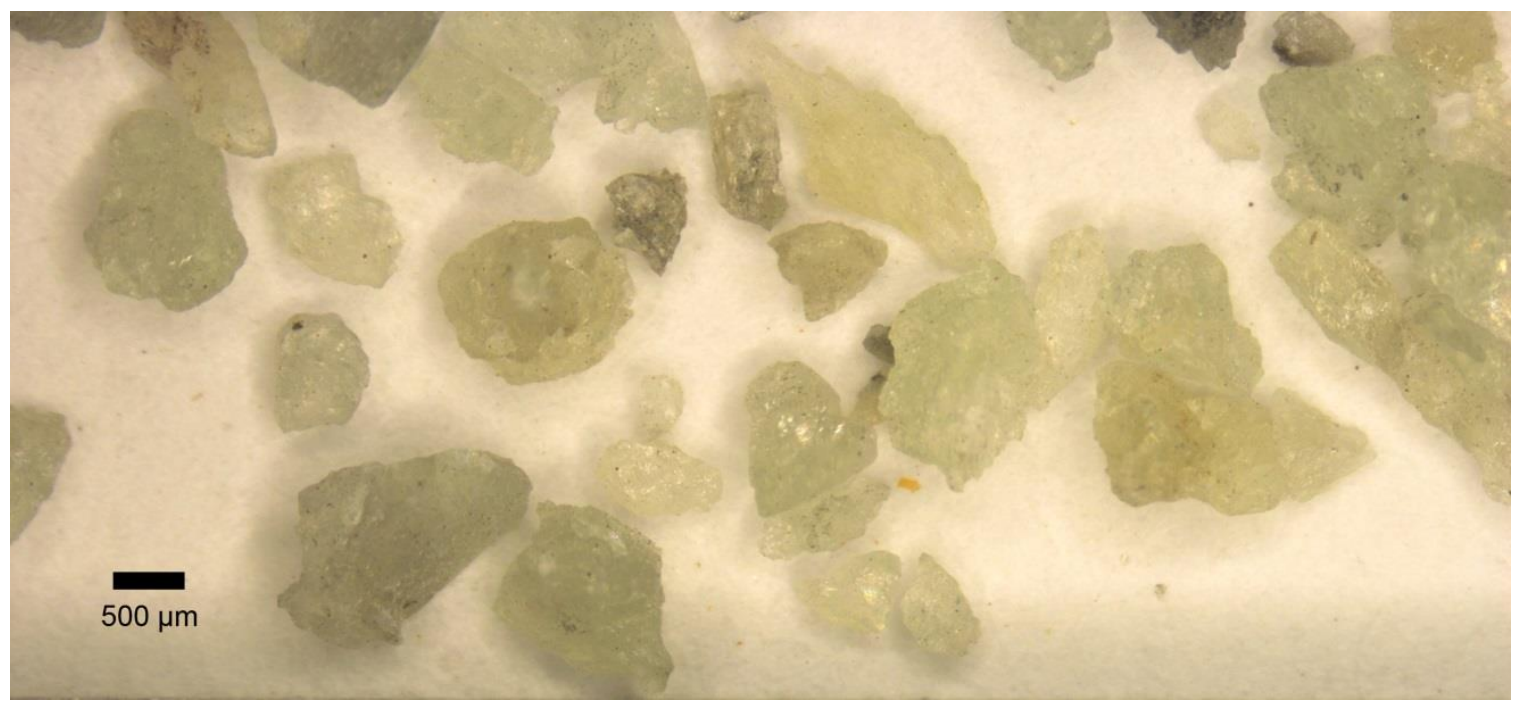

Figure 8. Olivine, coarse fraction $(150-1000 \mu \mathrm{m})$ before leaching. Sizes shown are not intended to be representative.

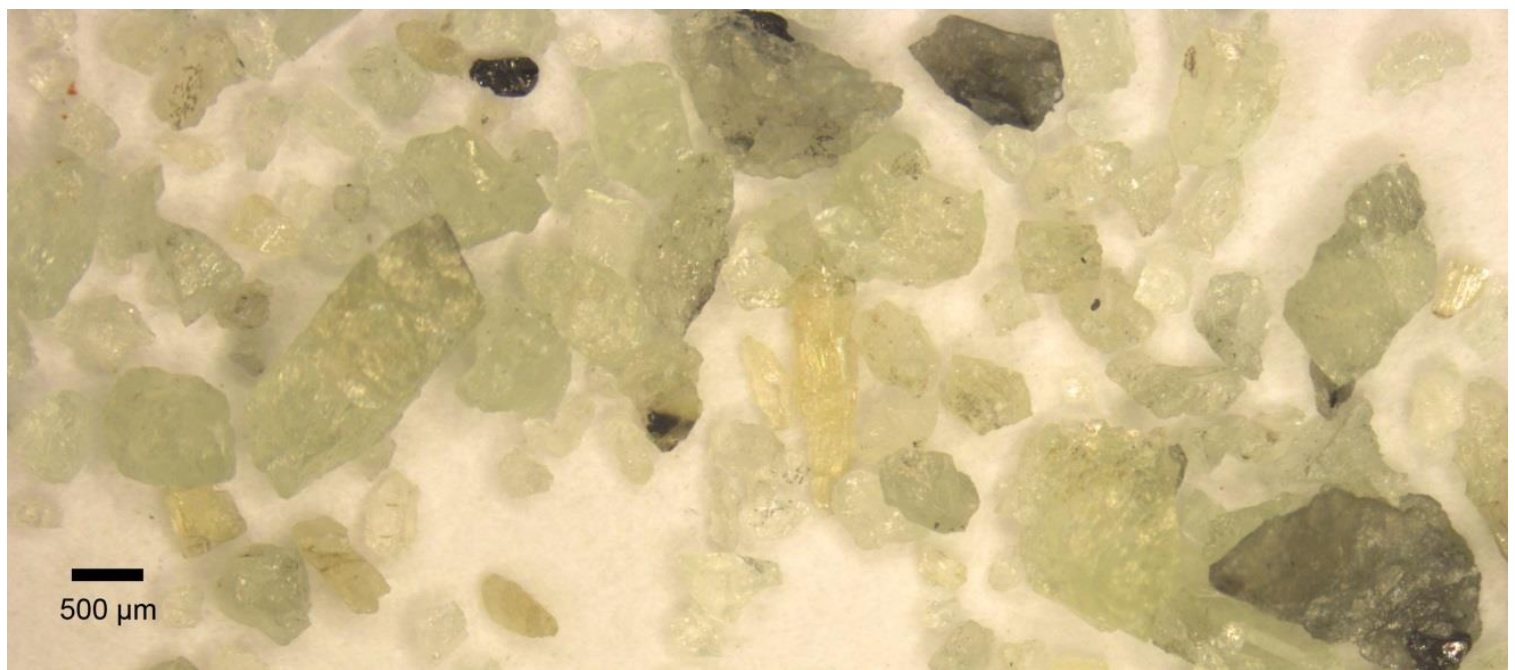

Figure 9. Olivine, coarse fraction $(150-1000 \mu \mathrm{m})$ after leaching in Solution A (Experiment O101). Sizes shown are not intended to be representative. This sample had an apparent loss over 109 days of $2.6 \%$ of its mass (Table 3 ), which may have been due to loss during recovery and filtering, or dissolution of mineral impurities. 


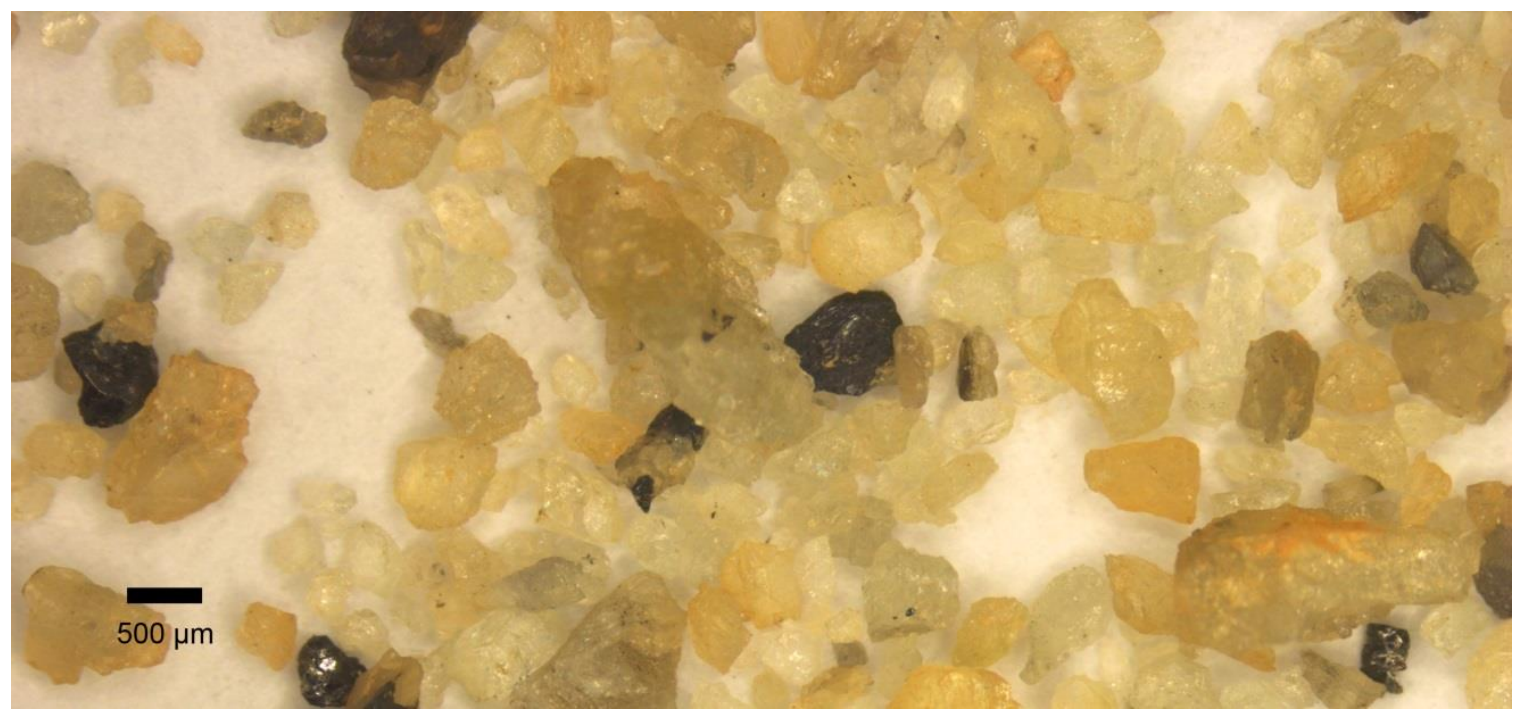

Figure 10. Olivine, coarse fraction (150-1000 $\mu \mathrm{m})$ after leaching in Solution B (Experiment O109). Note that the Fe-oxide coating on grains is likely due to precipitation of the Fe from the leaching solution. Sizes shown are not intended to be representative. This sample had an apparent loss over 109 days of $1.2 \%$ of its mass (Table 3), which may have been due to loss during recovery and filtering, or dissolution of mineral impurities.

Table 3. Mass loss of garnet (G-) and olivine (O-) during selected leaching experiments (weights in grams).

\begin{tabular}{lccccc}
\hline & Initial Weight & Final Weight & Difference & \% Loss & Days \\
\hline O101 & 0.5015 & 0.4886 & 0.0129 & 2.57 & 109 \\
O109 & 0.4960 & 0.4902 & 0.0058 & 1.19 & 109 \\
G101 & 0.4967 & 0.4920 & 0.0047 & 0.95 & 109 \\
G109 & 0.5040 & 0.4915 & 0.0125 & 2.48 & 109 \\
\hline
\end{tabular}

\subsubsection{Pyrite Leaching Experiments}

In contrast to the appearance and leachate chemical analysis data for garnet and olivine (above), reactions of pyrite with the leaching solutions were obvious in both photographic data (Figure 11 through Figure 13) and chemical leaching data. The pyrite before leaching was bright; it had a metallic luster and gold color. After leaching, the formation of crusts of Fe-oxides and/or hydroxide (the solid reaction products were not analyzed) can be seen to have formed over all surfaces.

Leaching data for pyrites showed that sulfur concentrations increased for most experiments over time (e.g., Figure 14). Because complete dissolution of pyrite would have occurred once the concentration of sulfur in solution reached an average of about 53,500 ppb in solutions diluted 100x from the sampled solution (10,700 for P1, which had $100 \mathrm{mg}$ of pyrite, rather than $500 \mathrm{mg}$ ), in all the following diagrams reaction progress can be seen in relation to the concentration. Only one experiment shown, P5 in Figure 14, approaches the concentration indicative of complete dissolution. Data for the leaching reactions are given in Table A.2, and prominent results are shown in the figures that follow. 


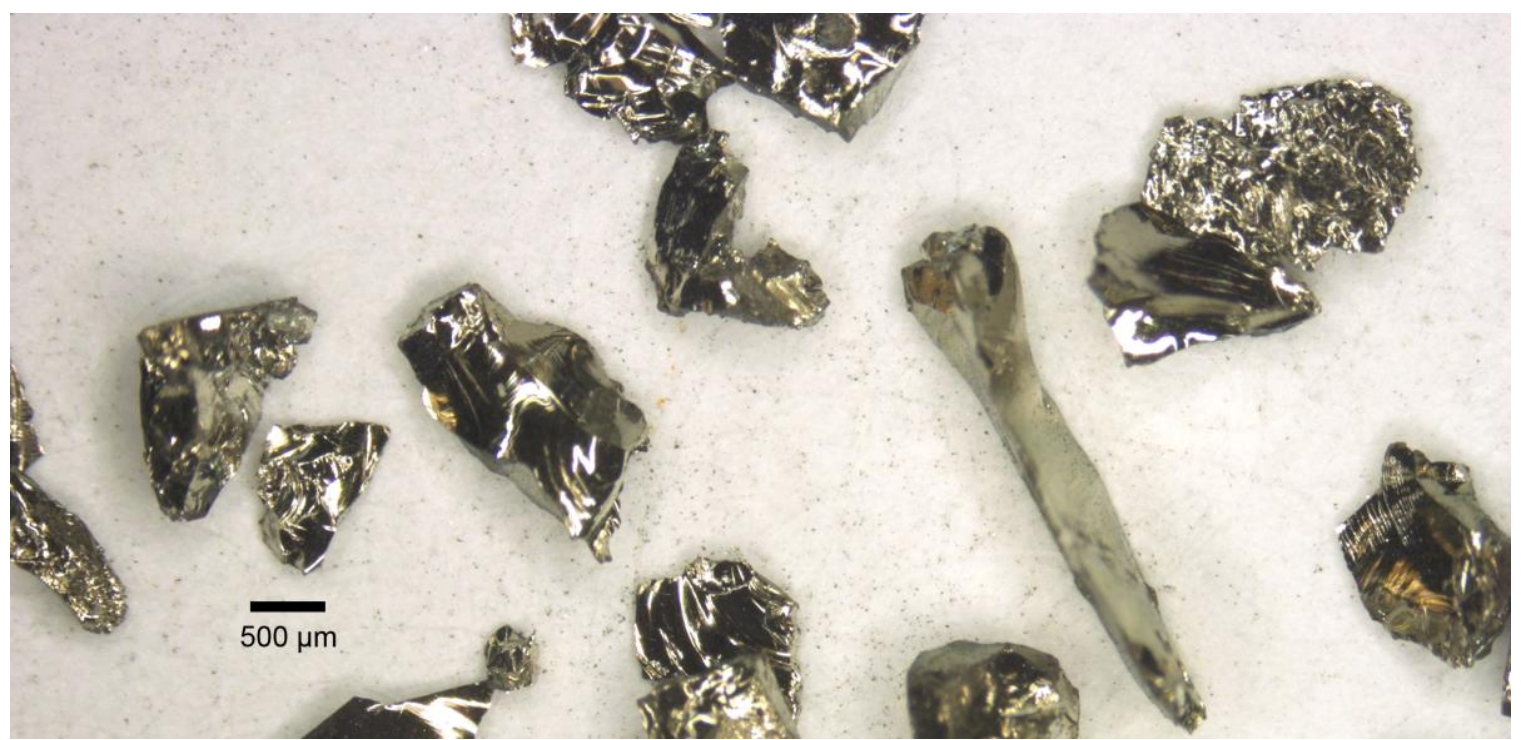

Figure 11. Pyrite, coarse fraction $(150-1000 \mu \mathrm{m})$ before leaching. Sizes shown are not intended to be representative.

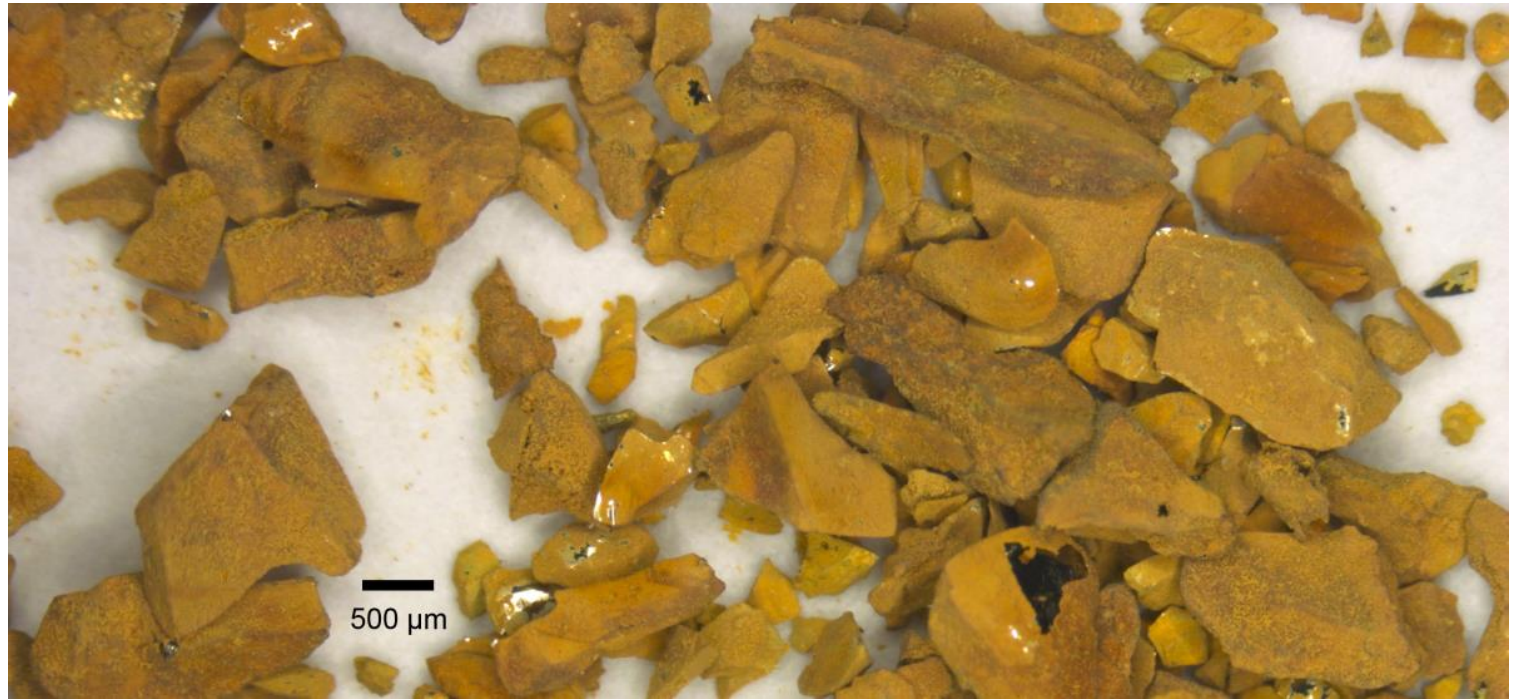

Figure 12. Pyrite, coarse fraction $(150-1000 \mu \mathrm{m})$ after leaching in Solution A (Experiment P101). Sizes shown are not intended to be representative. In this experiment, approximately $17 \%$ of the pyrite dissolved in 137 days, as indicated by the sulfur in solution (Table A.2). 


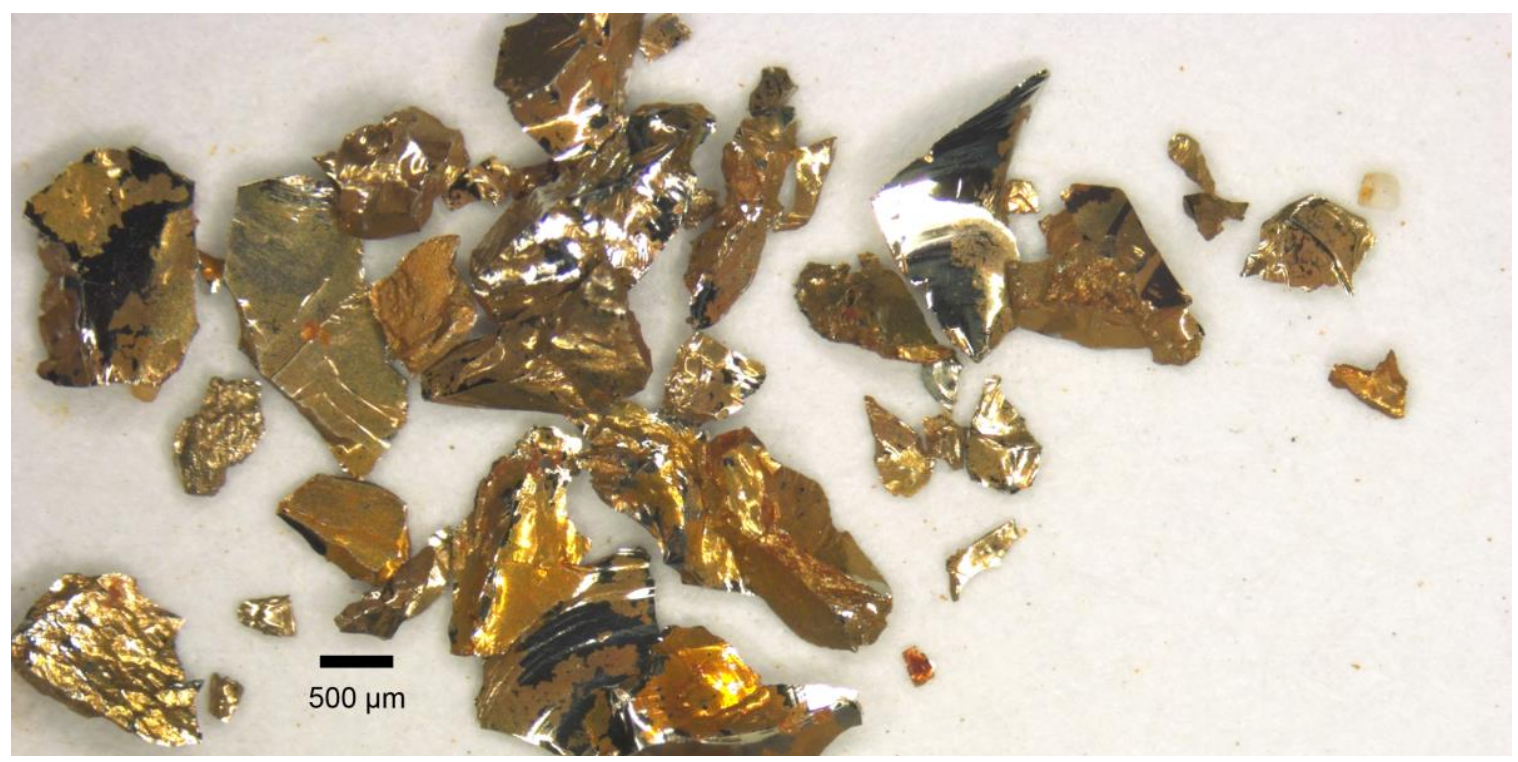

Figure 13. Pyrite, coarse fraction $(150-1000 \mu \mathrm{m})$ after leaching in Solution B (Experiment P109). Sizes shown are not intended to be representative. In this experiment, approximately $3.1 \%$ of the pyrite dissolved in 137 days, as indicated by the sulfur in solution (Table A.2).

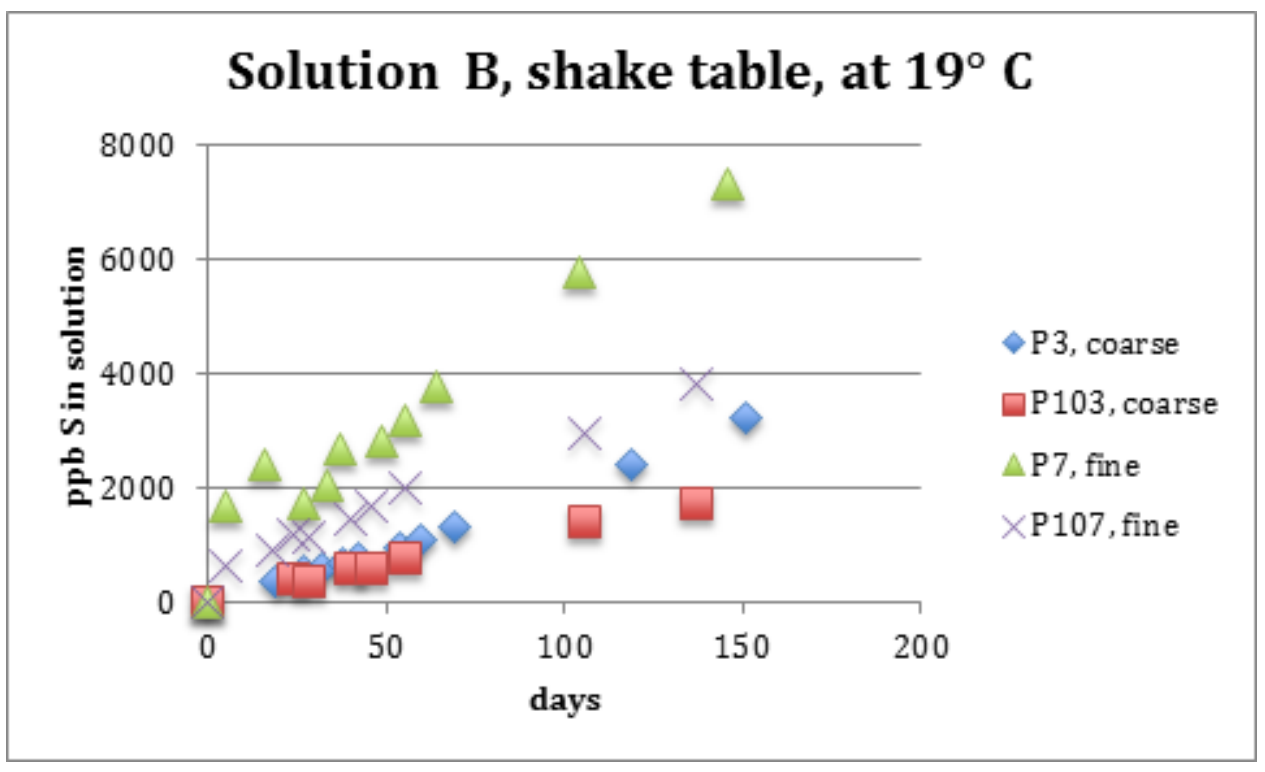

Figure 14. The effects of grain size in Solution B. Experiments P3 and P103 both reacted more quickly than did their coarse-grain equivalents P7 and P107. 


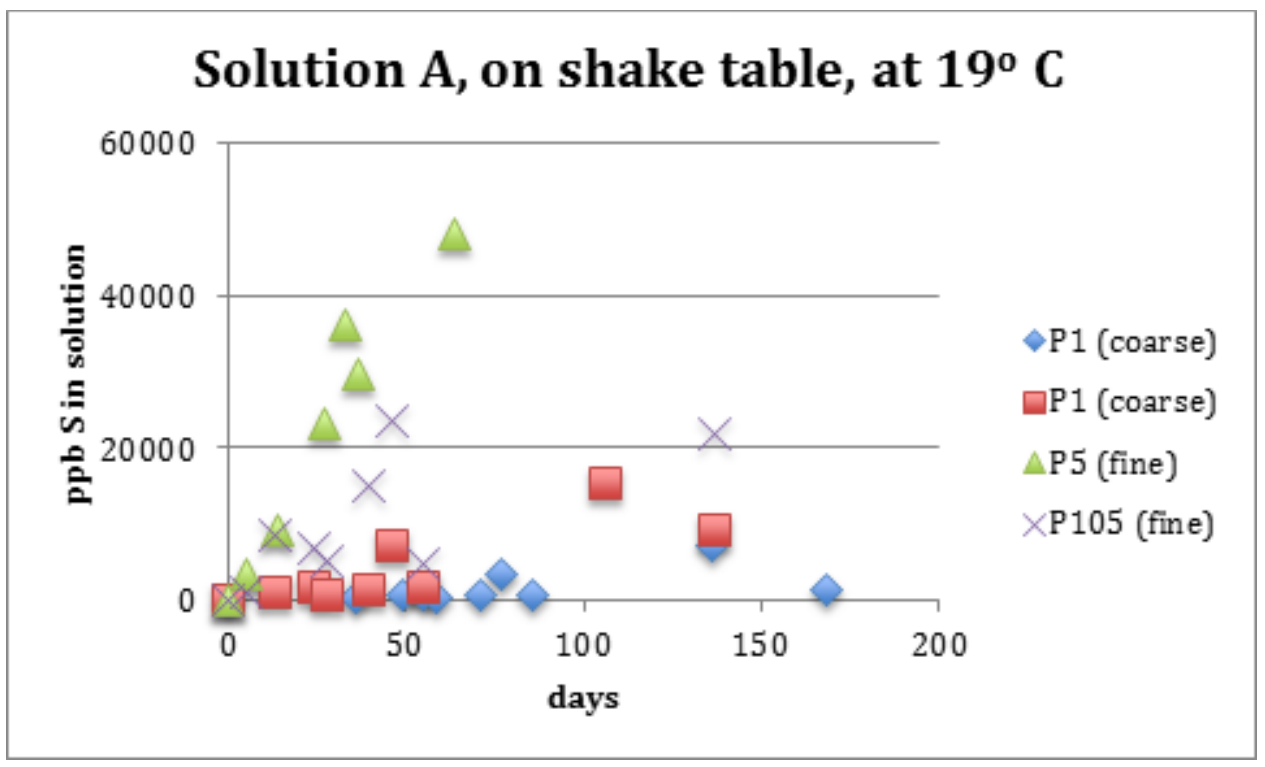

Figure 15. The effects of grain size in Solution A are shown here. The two fine-grained samples reacted much more quickly, with P5 reaching apparent complete dissolution at 64 days. Note also that they reached higher degrees of dissolution (S concentration) than did their equivalents in Solution B in Figure 14.

\subsubsection{Solution Composition When Open to Air}

Reactions among the Solution A experiments progressed faster and the detection of reaction products occurred before those of Solution B. In fact experiments P4, P104, P8, and P108, which were open to air at $19^{\circ} \mathrm{C}$ in Solution B, made minimal progress, probably because of the precipitation of salts on the pyrite. This precipitation may have completely armored the pyrite and thus precluded further oxidation of the iron and sulfur. Sulfur was not detected in the solutions.

\subsubsection{Effect of Temperature}

Reactions run at $40^{\circ} \mathrm{C}$ did not differ greatly from those run at $19^{\circ} \mathrm{C}$ (Figure 16). In these experiments, the solutions were all Solution B. It might be surmised that the presence of components in Solution B negatively affected the alteration of the pyrite, such that the elevated temperature did not result in more rapid reaction progress.

\subsubsection{Effect of Grain Size}

The variable with the greatest effect on reaction rate was grain size; the fine-grained pyrite reacted much faster than the coarse-grained pyrite. Reactions among the fine-grained $(<53 \mu \mathrm{m})$ samples occurred before and ran faster than those of the coarse fraction $(150-1000 \mu \mathrm{m})$, as seen in Figure 14, Figure 15, and Figure 17. In some fine-grained samples (e.g., Figure 16) reaction completion within a few weeks was indicated by the sulfur concentration of the leach solution. 


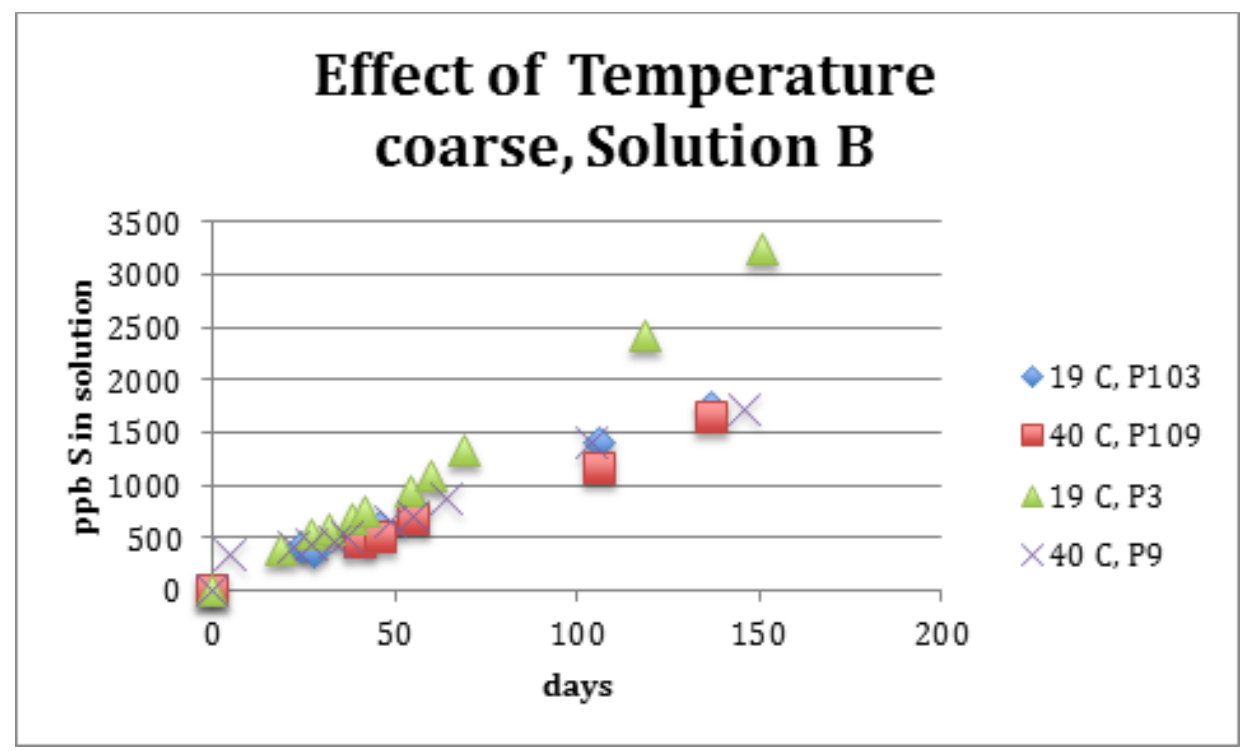

Figure 16. The effects of temperature in Solution B. Experiments $\mathrm{P} 3 / \mathrm{P} 103$ at $19^{\circ} \mathrm{C}$ ran at the same rate or faster than those at $40^{\circ} \mathrm{C}(\mathrm{P} 9 / \mathrm{P} 109)$. This may be an effect of the shaker table increasing reaction rates.

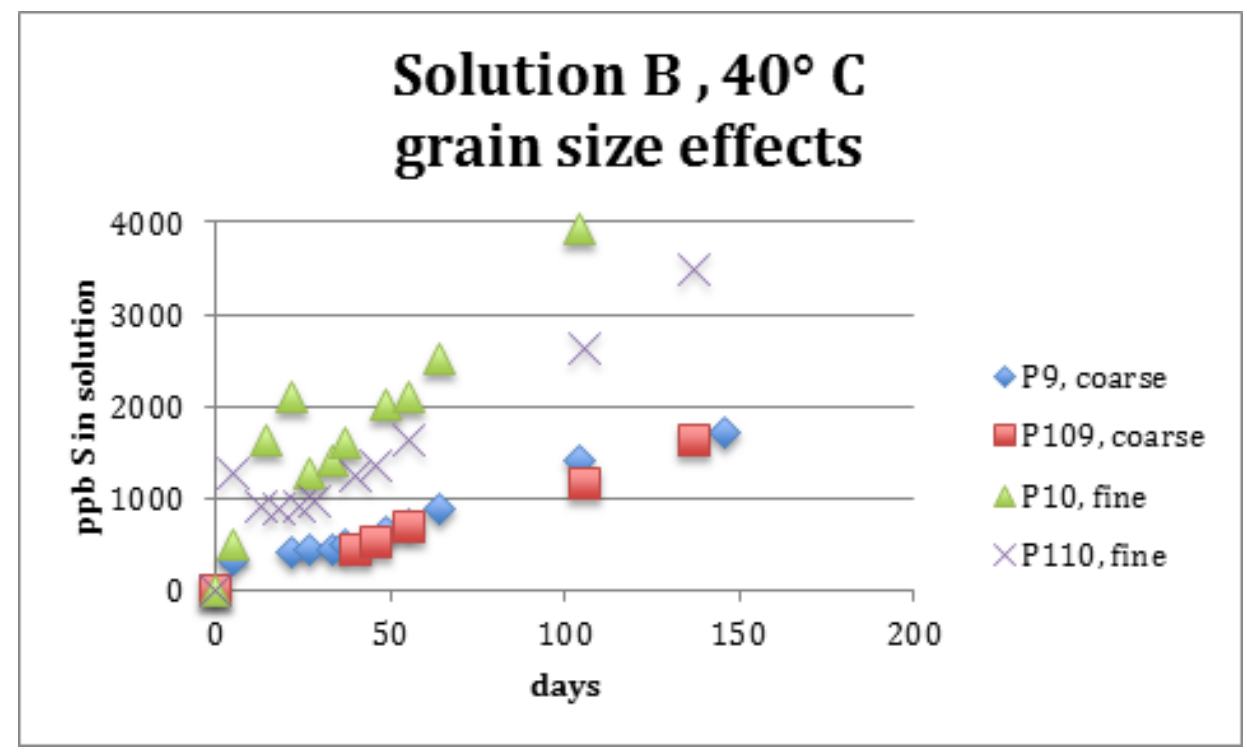

Figure 17. At $40^{\circ} \mathrm{C}$, as at $19^{\circ} \mathrm{C}$ (see Figure 15), the grain size has a large effect on reaction rate; the fine-grained (P10/P110) experiments reacted more quickly than the coarse-grained experiments.

\subsubsection{Projection to Reaction Completion Times}

All experiments except P1 were run with $500 \mathrm{mg}$ of pyrite in $50 \mathrm{~mL}$ of reaction solution. P1 was run with $100 \mathrm{mg}$ pyrite in $50 \mathrm{~mL}$ of Solution A. The reactions would have been judged to have run to completion when $100 \%$ of the pyrite was dissolved. This would have occurred when the sulfur concentration in solution reached about $54,000 \mathrm{ppb}$ in the $100 \mathrm{x}$ dilutions $(5.4 \mathrm{mg} / \mathrm{mL}$ in the leach solutions). These reaction times were extrapolated with a linear trend-line from the reaction progress in 
the various experiments (Figure 18 through Figure 20). The reaction times (time to intersection with the concentration indicating complete dissolution) ranged from months to years, except for experiments $\mathrm{P} 4$, P8, P104, and P108, in which precipitation of salts seems to have interfered with reaction progress.

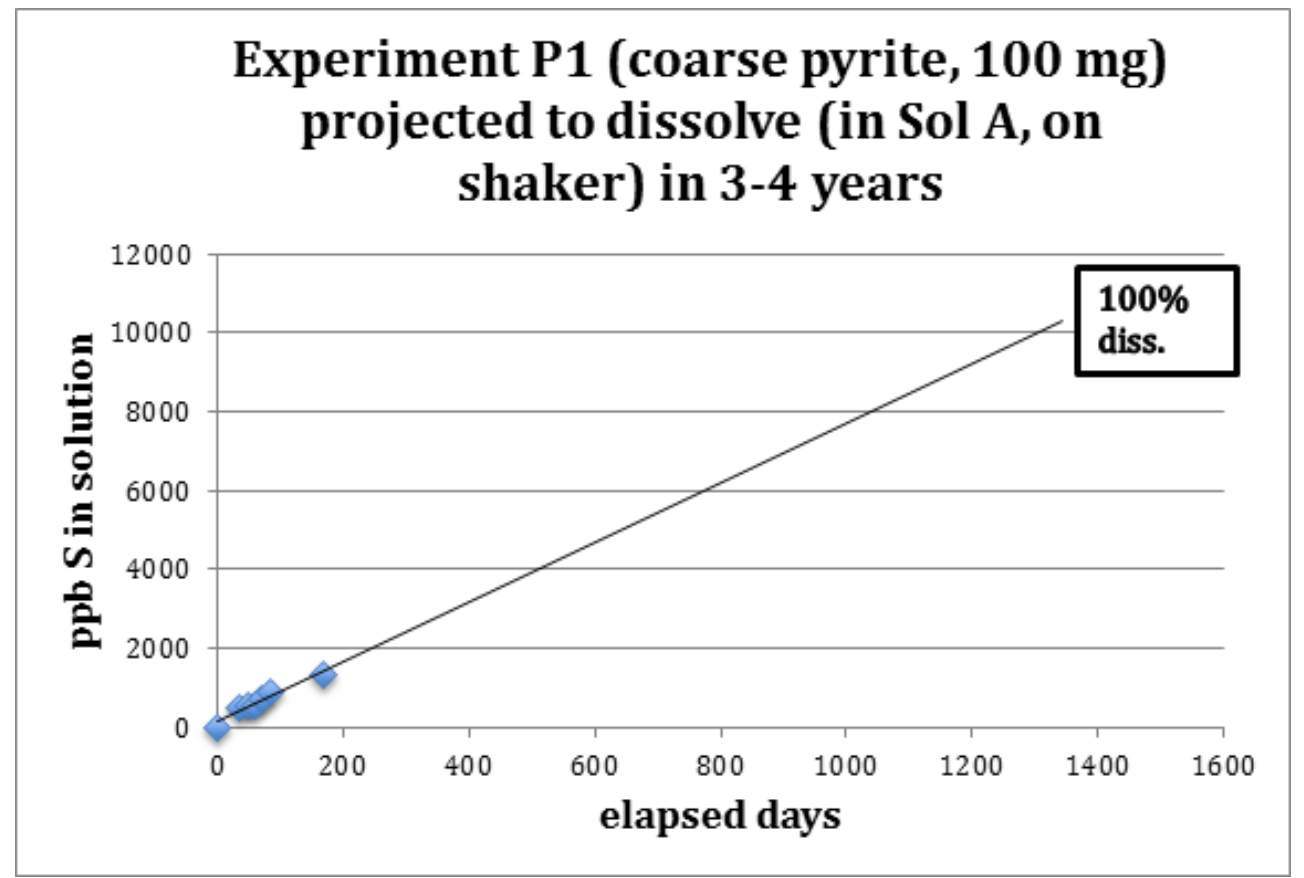

Figure 18. In this experiment, $100 \mathrm{mg}$ of pyrite would be expected to completely dissolve in about 3 to 4 years, when the solution concentration would reach about 11,000 ppb.

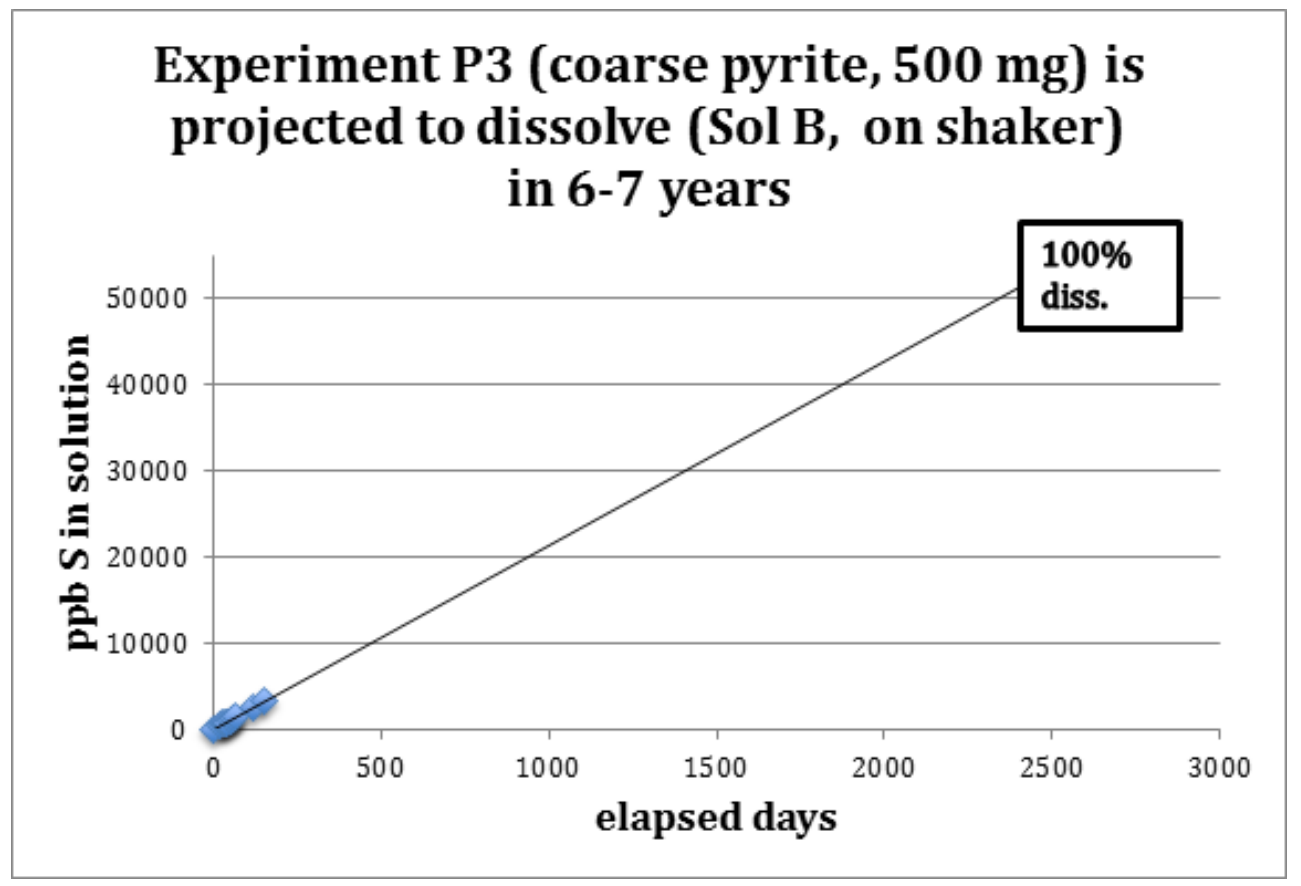

Figure 19. Coarse pyrite reaction in Solution $B$ at $19^{\circ} \mathrm{C}$ was slower than in Solution A at $19^{\circ} \mathrm{C}$ on the shaker table (Figure 18). In this experiment, the $500 \mathrm{mg}$ of pyrite are projected to have taken 6 to 7 years to dissolve. 


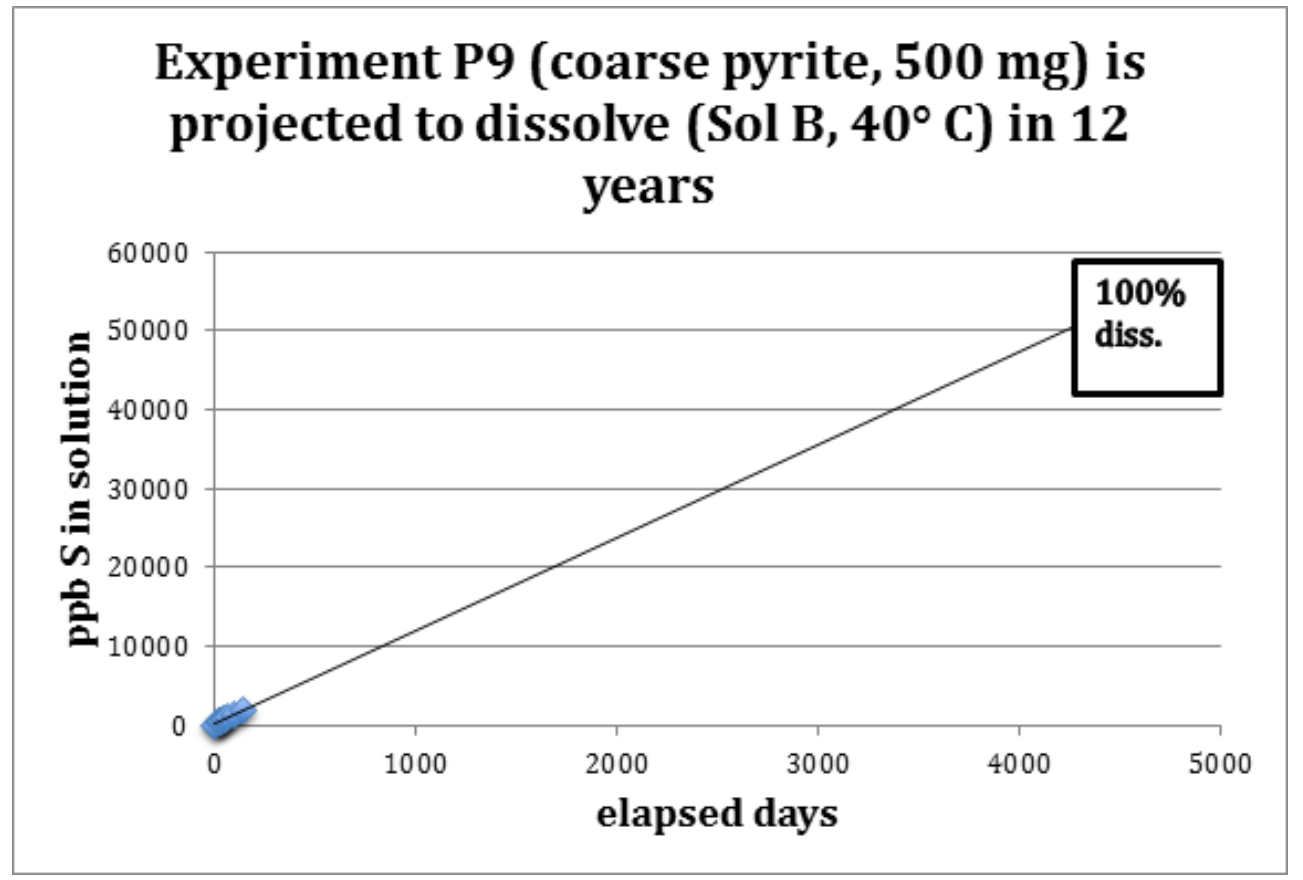

Figure 20. In this experiment, carried out in Solution B, dissolution of the pyrite is indicated to be slower than reactions in Solution A. The $500 \mathrm{mg}$ of pyrite are projected to have taken 12 years to dissolve.

\subsection{Interpretation of Results}

Except for experiments P4, P8, P104, and P108, experiments in Solution B left open to air (and which hence precipitated thick crusts, probably Na salts) over the pyrite, all pyrite leaching experiments showed significant progress. This progress was indicated by the development of increased sulfur concentrations over time. The salt encrustations of these four reaction series no doubt impeded reaction progress for the two Solution B reactions (P4/P104, P8/P108) that were open to air.

For the other reaction series, the higher reaction rates seen for fine grain size are most significant. For some of the reaction series considerable scatter precludes fitting a single reaction progress line to the concentrations over time. This is probably the result of faults in the experimental design, such as a nonstandardized sample collection method. If the leach solutions were highly stratified, as is likely because of their high total dissolved solids concentrations (and hence density), slight differences in the depth of pipette tip insertion into the solution would yield highly variable concentration results.

Coarser grain sizes, such as would be used in water-jet cutting, show reaction rates indicative of complete digestion within a decade. Note that the grain size of this coarse abrasive would be reduced significantly by use. Therefore, it is estimated that reaction times until complete dissolution of pyrite would be bracketed between the "coarse" and "fine" reaction times. This means that dissolution would be complete in less than a decade. 


\subsection{References}

American Society for Testing and Materials (ASTM) Standard A615/A615M. 2003. "Specification for Deformed and Plain Carbon-Steel Bars for Concrete Reinforcement." ASTM International,

West Conshohocken, Pennsylvania, DOI: 10.1520/A0615_A0615M-12, www.astm.org.

American Society for Testing and Materials (ASTM) Standard A706/A706M. 2003. "Specification for Low-Alloy Steel Deformed and Plain Bars for Concrete Reinforcement." ASTM International, West Conshohocken, Pennsylvania, DOI: 10.1520/A0706_A0706M-09B, www.astm.org.

Klein C and CS Hurlbut. 1985. Manual of Mineralogy, 20th ed. John Wiley \& Sons, New York. 
I

\section{Data Tables}





\section{Appendix}

\section{Data Tables}

Table A.1. Experiment Key

\begin{tabular}{ccl}
\hline Experiment & Start Date & \\
\hline P1 & $7 / 31 / 12$ & $150-1000 \mu \mathrm{m}: \mathrm{NaOH}+$ Shake Table \\
P2 & $8 / 1 / 12$ & $150-1000 \mu \mathrm{m}: \mathrm{NaOH}+$ Open Air \\
P3 & $8 / 17 / 12$ & $150-1000 \mu \mathrm{m}:$ Nitrate/Nitrite + Shake Table \\
P4 & $8 / 17 / 12$ & $150-1000 \mu \mathrm{m}:$ Nitrate/Nitrite + Open Air \\
P5 & $8 / 22 / 12$ & $<53 \mu \mathrm{m}: \mathrm{NaOH}+$ Shake Table \\
P6 & $8 / 22 / 12$ & $<53 \mu \mathrm{m}: \mathrm{NaOH}+$ Open Air \\
P7 & $8 / 22 / 12$ & $<53 \mu \mathrm{m}: \mathrm{Nitrate} / \mathrm{Nitrite}+$ Shake Table \\
P8 & $8 / 22 / 12$ & $<53 \mu \mathrm{m}: \mathrm{Nitrate} / \mathrm{Nitrite}+$ Open Air \\
P9 & $8 / 22 / 12$ & $150-1000 \mu \mathrm{m}:$ Nitrate/Nitrite $+40^{\circ} \mathrm{C}$ \\
P10 & $8 / 22 / 12$ & $<53 \mu \mathrm{m}: \mathrm{Nitrate} / \mathrm{Nitrite}+40^{\circ} \mathrm{C}$ \\
P101 & $8 / 31 / 12$ & $150-1000 \mu \mathrm{m}: \mathrm{NaOH}+$ Shake Table \\
P102 & $8 / 31 / 12$ & $150-1000 \mu \mathrm{m}: \mathrm{NaOH}+$ Open Air \\
P103 & $8 / 31 / 12$ & $150-1000 \mu \mathrm{m}: \mathrm{Nitrate} / \mathrm{Nitrite}+$ Shake Table \\
P104 & $8 / 31 / 12$ & $150-1000 \mu \mathrm{m}: \mathrm{Nitrate} / \mathrm{Nitrite}+$ Open Air \\
P105 & $8 / 31 / 12$ & $<53 \mu \mathrm{m}: \mathrm{NaOH}+$ Shake Table \\
P106 & $8 / 31 / 12$ & $<53 \mu \mathrm{m}: \mathrm{NaOH}+$ Open Air \\
P107 & $8 / 31 / 12$ & $<53 \mu \mathrm{m}: \mathrm{Nitrate} / \mathrm{Nitrite}+$ Shake Table \\
P108 & $8 / 31 / 12$ & $<53 \mu \mathrm{m}: \mathrm{Nitrate} / \mathrm{Nitrite}+$ Open Air \\
P109 & $8 / 31 / 12$ & $150-1000 \mu \mathrm{m}:$ Nitrate/Nitrite $+40^{\circ} \mathrm{C}$ \\
P110 & $8 / 31 / 12$ & $<53 \mu \mathrm{m}: \mathrm{Nitrate} / \mathrm{Nitrite}+40^{\circ} \mathrm{C}$ \\
\hline
\end{tabular}


Table A.2. Leach solution concentrations, in ppb (ng/g). Experiment identities (e.g., P1, P2, etc. correspond to those in Table A.1. Experiments with "O" or "G" prefixes have the same starting dates, grain sizes, leaching solution compositions, and conditions as the equivalent experiments with "P" prefixes.

\begin{tabular}{|c|c|c|c|c|c|}
\hline \multicolumn{6}{|c|}{ P1 } \\
\hline Day & $\begin{array}{c}\text { Aluminum } \\
\text { Avg }\end{array}$ & $\begin{array}{l}\text { Iron } \\
\text { Avg }\end{array}$ & $\begin{array}{l}\text { Magnesium } \\
\text { Avg }\end{array}$ & $\begin{array}{l}\text { Silicon } \\
\text { Avg }\end{array}$ & $\begin{array}{c}\text { Sulfur } \\
\text { Avg }\end{array}$ \\
\hline 0 & & & & & 0 \\
\hline 14 & 77 & 20 & 21 & ND & ND \\
\hline 21 & 79 & 15 & 17 & ND & ND \\
\hline 27 & ND & ND & ND & ND & ND \\
\hline 36 & ND & ND & 4 & ND & 453 \\
\hline 44 & ND & ND & ND & ND & ND \\
\hline 49 & ND & ND & ND & ND & 559 \\
\hline 55 & ND & ND & ND & ND & 812 \\
\hline 59 & ND & 41 & 4 & ND & 545 \\
\hline 66 & 752 & 101 & 135 & ND & \#NA \\
\hline 71 & ND & ND & 12 & ND & 710 \\
\hline 77 & ND & 448 & 12 & ND & 3365 \\
\hline 86 & ND & ND & 12 & ND & 880 \\
\hline 135 & & & & & 7328 \\
\hline \multicolumn{6}{|c|}{$\mathbf{P 2}$} \\
\hline Day & $\begin{array}{c}\text { Aluminum } \\
\text { Avg }\end{array}$ & $\begin{array}{l}\text { Iron } \\
\text { Avg }\end{array}$ & $\begin{array}{l}\text { Magnesium } \\
\text { Avg }\end{array}$ & $\begin{array}{c}\text { Silicon } \\
\text { Avg }\end{array}$ & $\begin{array}{c}\text { Sulfur } \\
\text { Avg }\end{array}$ \\
\hline 0 & & & & & 0 \\
\hline 14 & 78 & 38 & 20 & ND & 566 \\
\hline 20 & 76 & 12 & 16 & ND & 615 \\
\hline 26 & ND & ND & ND & ND & 848 \\
\hline 35 & ND & 11 & 4 & ND & 948 \\
\hline 43 & ND & 12 & ND & ND & 2000 \\
\hline 48 & ND & 11 & 26 & ND & 1180 \\
\hline 54 & ND & ND & ND & ND & 1380 \\
\hline 58 & ND & 19 & ND & ND & 1230 \\
\hline 65 & 178 & 36 & 35 & 535 & \#NA \\
\hline 70 & ND & 57 & 12 & ND & 1460 \\
\hline 76 & ND & 20 & 12 & ND & 2740 \\
\hline 85 & ND & 206 & 14 & ND & 1895 \\
\hline 134 & & & & & 7533 \\
\hline \multicolumn{6}{|c|}{$\mathbf{P 3}$} \\
\hline Day & $\begin{array}{c}\text { Aluminum } \\
\text { Avg }\end{array}$ & $\begin{array}{l}\text { Iron } \\
\text { Avg }\end{array}$ & $\begin{array}{c}\text { Magnesium } \\
\text { Avg }\end{array}$ & $\begin{array}{c}\text { Silicon } \\
\text { Avg }\end{array}$ & $\begin{array}{c}\text { Sulfur } \\
\text { Avg }\end{array}$ \\
\hline 0 & & & & & 0 \\
\hline 4 & 112000 & 342 & 15 & ND & ND \\
\hline 10 & 81600 & 673 & ND & ND & ND \\
\hline 19 & 126000 & 329 & ND & ND & 390 \\
\hline 27 & 126500 & 406 & ND & ND & 546 \\
\hline 32 & 111000 & 178 & ND & ND & 587 \\
\hline 38 & 122000 & 103 & ND & ND & 691 \\
\hline 42 & 126500 & 123 & ND & ND & 757 \\
\hline
\end{tabular}




\begin{tabular}{cccccc}
\hline 49 & 112000 & 61 & 21 & ND & \#NA \\
\hline 54 & 112000 & 74 & ND & ND & 947
\end{tabular}

Table A.2. (contd)

\begin{tabular}{|c|c|c|c|c|c|}
\hline Day & $\begin{array}{c}\text { Aluminum } \\
\text { Avg }\end{array}$ & $\begin{array}{l}\text { Iron } \\
\text { Avg }\end{array}$ & $\begin{array}{l}\text { Magnesium } \\
\text { Avg }\end{array}$ & $\begin{array}{c}\text { Silicon } \\
\text { Avg }\end{array}$ & $\begin{array}{c}\text { Sulfur } \\
\text { Avg }\end{array}$ \\
\hline 60 & 117500 & 64 & ND & ND & 1100 \\
\hline 69 & 110000 & 182 & ND & ND & 1335 \\
\hline 118 & & & & & 2426 \\
\hline \multicolumn{6}{|c|}{ P4 } \\
\hline Day & $\begin{array}{c}\text { Aluminum } \\
\text { Avg }\end{array}$ & $\begin{array}{l}\text { Iron } \\
\text { Avg }\end{array}$ & $\begin{array}{l}\text { Magnesium } \\
\text { Avg }\end{array}$ & $\begin{array}{c}\text { Silicon } \\
\text { Avg }\end{array}$ & $\begin{array}{c}\text { Sulfur } \\
\text { Avg }\end{array}$ \\
\hline 0 & & & & & 0 \\
\hline 4 & 124000 & 180 & 16 & ND & ND \\
\hline 10 & 57400 & 1800 & 4 & ND & ND \\
\hline 19 & 145000 & 175 & ND & ND & ND \\
\hline 27 & 167000 & 182 & ND & ND & ND \\
\hline 32 & 184000 & 377 & ND & ND & ND \\
\hline 38 & 234000 & 184 & ND & ND & 338 \\
\hline 42 & 101450 & 118 & ND & ND & ND \\
\hline 49 & 52850 & 66 & 18 & ND & ND \\
\hline 54 & 42050 & 31 & ND & ND & 341 \\
\hline 60 & 23800 & 30 & ND & ND & ND \\
\hline 69 & 11750 & ND & ND & ND & 332 \\
\hline 118 & & & & & 368 \\
\hline \multicolumn{6}{|c|}{ P5 } \\
\hline Day & $\begin{array}{c}\text { Aluminum } \\
\text { Avg }\end{array}$ & $\begin{array}{l}\text { Iron } \\
\text { Avg }\end{array}$ & $\begin{array}{l}\text { Magnesium } \\
\text { Avg }\end{array}$ & $\begin{array}{c}\text { Silicon } \\
\text { Avg }\end{array}$ & $\begin{array}{c}\text { Sulfur } \\
\text { Avg }\end{array}$ \\
\hline 0 & & & & & 0 \\
\hline 5 & ND & ND & 13 & ND & 3610 \\
\hline 14 & ND & ND & 4 & ND & 9275 \\
\hline 22 & ND & 80 & 12 & ND & \#NA \\
\hline 27 & ND & ND & 23 & ND & 23350 \\
\hline 33 & ND & ND & ND & ND & 36200 \\
\hline 37 & 162 & 28 & 34 & ND & 29850 \\
\hline 44 & 183 & 29 & 36 & ND & \#NA \\
\hline 49 & ND & 16 & 12 & ND & 80050 \\
\hline 55 & ND & ND & ND & ND & 92550 \\
\hline 64 & ND & ND & 13 & ND & 48150 \\
\hline \multicolumn{6}{|c|}{ P6 } \\
\hline Day & $\begin{array}{c}\text { Aluminum } \\
\text { Avg }\end{array}$ & $\begin{array}{l}\text { Iron } \\
\text { Avg }\end{array}$ & $\begin{array}{l}\text { Magnesium } \\
\text { Avg }\end{array}$ & $\begin{array}{c}\text { Silicon } \\
\text { Avg }\end{array}$ & $\begin{array}{c}\text { Sulfur } \\
\text { Avg }\end{array}$ \\
\hline 0 & & & & & 0 \\
\hline 5 & ND & ND & ND & ND & 867 \\
\hline 14 & ND & 37 & 5 & ND & 4720 \\
\hline 22 & ND & 21 & ND & ND & \#NA \\
\hline 27 & ND & 10 & ND & ND & 7180 \\
\hline 33 & ND & 11 & ND & ND & 11950 \\
\hline
\end{tabular}


Table A.2. (contd)

\begin{tabular}{|c|c|c|c|c|c|}
\hline Day & $\begin{array}{l}\text { Aluminum } \\
\text { Avg }\end{array}$ & $\begin{array}{l}\text { Iron } \\
\text { Avg }\end{array}$ & $\begin{array}{l}\text { Magnesium } \\
\text { Avg }\end{array}$ & $\begin{array}{l}\text { Silicon } \\
\text { Avg }\end{array}$ & $\begin{array}{c}\text { Sulfur } \\
\text { Avg }\end{array}$ \\
\hline 37 & ND & 35 & ND & ND & 9785 \\
\hline 44 & 182 & 45 & 37 & 154 & \#NA \\
\hline 49 & ND & 27 & 12 & ND & 27100 \\
\hline 55 & ND & 29 & 13 & ND & 30800 \\
\hline 64 & ND & ND & 12 & ND & 14700 \\
\hline 104 & & & & & 95256 \\
\hline \multicolumn{6}{|c|}{ P7 } \\
\hline Day & $\begin{array}{c}\text { Aluminum } \\
\text { Avg }\end{array}$ & $\begin{array}{l}\text { Iron } \\
\text { Avg }\end{array}$ & $\begin{array}{c}\text { Magnesium } \\
\text { Avg }\end{array}$ & $\begin{array}{c}\text { Silicon } \\
\text { Avg }\end{array}$ & $\begin{array}{c}\text { Sulfur } \\
\text { Avg }\end{array}$ \\
\hline 0 & & & & & 0 \\
\hline 5 & 119000 & 1340 & ND & ND & 1710 \\
\hline 16 & 241000 & 816 & ND & ND & 2410 \\
\hline 22 & 123000 & 369 & ND & ND & $\#_{N A}{ }^{(a)}$ \\
\hline 27 & 108500 & 302 & ND & ND & 1730 \\
\hline 33 & 116500 & 267 & ND & ND & 2045 \\
\hline 37 & 125500 & 528 & ND & ND & 2690 \\
\hline 44 & 113500 & 317 & 33 & ND & \#NA \\
\hline 49 & 111500 & 160 & ND & ND & 2835 \\
\hline 55 & 114000 & 298 & ND & ND & 3195 \\
\hline 64 & 111000 & 300 & ND & ND & 3775 \\
\hline 104 & & & & & 5767 \\
\hline \multicolumn{6}{|c|}{ P8 } \\
\hline Day & $\begin{array}{c}\text { Aluminum } \\
\text { Avg }\end{array}$ & $\begin{array}{l}\text { Iron } \\
\text { Avg }\end{array}$ & $\begin{array}{c}\text { Magnesium } \\
\text { Avg }\end{array}$ & $\begin{array}{c}\text { Silicon } \\
\text { Avg }\end{array}$ & $\begin{array}{c}\text { Sulfur } \\
\text { Avg }\end{array}$ \\
\hline 0 & & & & & 0 \\
\hline 5 & 127000 & 20300 & 17 & ND & ND \\
\hline 14 & 141500 & 453 & ND & ND & 753 \\
\hline 22 & 165000 & 500 & ND & ND & 1009 \\
\hline 27 & 195500 & 531 & ND & ND & 1240 \\
\hline 33 & 285000 & 617 & ND & ND & 1615 \\
\hline 37 & 138500 & 353 & 19 & ND & 950 \\
\hline 44 & 95850 & 256 & 19 & 151 & \#NA \\
\hline 49 & 44250 & 94 & 5 & ND & 790 \\
\hline 55 & 33900 & 73 & ND & ND & 1040 \\
\hline 64 & 15100 & 23 & ND & ND & 1235 \\
\hline 104 & & & & & 1415 \\
\hline \multicolumn{6}{|c|}{ P9 } \\
\hline Day & $\begin{array}{l}\text { Aluminum } \\
\text { Avg }\end{array}$ & $\begin{array}{l}\text { Iron } \\
\text { Avg }\end{array}$ & $\begin{array}{l}\text { Magnesium } \\
\text { Avg }\end{array}$ & $\begin{array}{l}\text { Silicon } \\
\text { Avg }\end{array}$ & $\begin{array}{c}\text { Sulfur } \\
\text { Avg }\end{array}$ \\
\hline$\overline{0}$ & & & & & 0 \\
\hline 5 & 142000 & 406 & 17 & ND & 333 \\
\hline 14 & 132500 & 224 & ND & ND & ND \\
\hline 22 & 137000 & 474 & 4 & ND & 410 \\
\hline 27 & 121500 & 72 & ND & ND & 447 \\
\hline 33 & 127500 & 362 & ND & ND & 460 \\
\hline
\end{tabular}


Table A.2. (contd)

\begin{tabular}{|c|c|c|c|c|c|}
\hline Day & $\begin{array}{c}\text { Aluminum } \\
\text { Avg }\end{array}$ & $\begin{array}{l}\text { Iron } \\
\text { Avg }\end{array}$ & $\begin{array}{l}\text { Magnesium } \\
\text { Avg }\end{array}$ & $\begin{array}{l}\text { Silicon } \\
\text { Avg }\end{array}$ & $\begin{array}{c}\text { Sulfur } \\
\text { Avg }\end{array}$ \\
\hline 37 & 129500 & 220 & ND & ND & 505 \\
\hline 44 & 118000 & 151 & 23 & ND & \#NA \\
\hline 49 & 124500 & 41 & ND & ND & 651 \\
\hline 55 & 126000 & 77 & ND & ND & 712 \\
\hline 64 & 126500 & 121 & ND & ND & 875 \\
\hline 104 & & & & & 1414 \\
\hline \multicolumn{6}{|c|}{ P10 } \\
\hline Day & $\begin{array}{c}\text { Aluminum } \\
\text { Avg }\end{array}$ & $\begin{array}{l}\text { Iron } \\
\text { Avg }\end{array}$ & $\begin{array}{c}\text { Magnesium } \\
\text { Avg }\end{array}$ & $\begin{array}{c}\text { Silicon } \\
\text { Avg }\end{array}$ & $\begin{array}{c}\text { Sulfur } \\
\text { Avg }\end{array}$ \\
\hline 0 & & & & & 0 \\
\hline 5 & 113000 & 249 & ND & ND & 494 \\
\hline 14 & 120500 & 980 & ND & ND & 1635 \\
\hline 22 & 134000 & 949 & ND & ND & 2110 \\
\hline 27 & 120500 & 106 & ND & ND & 1275 \\
\hline 33 & 124500 & 64 & ND & ND & 1420 \\
\hline 37 & 132500 & 122 & ND & ND & 1605 \\
\hline 44 & 117000 & 271 & 24 & ND & \#NA \\
\hline 49 & 122000 & 169 & ND & ND & 2030 \\
\hline 55 & 121000 & 40 & ND & ND & 2115 \\
\hline 64 & 120000 & 179 & ND & ND & 2530 \\
\hline 104 & & & & & 3925 \\
\hline \multicolumn{6}{|c|}{ P101 } \\
\hline Day & $\begin{array}{l}\text { Aluminum } \\
\text { Avg }\end{array}$ & $\begin{array}{l}\text { Iron } \\
\text { Avg }\end{array}$ & $\begin{array}{l}\text { Magnesium } \\
\text { Avg }\end{array}$ & $\begin{array}{l}\text { Silicon } \\
\text { Avg }\end{array}$ & $\begin{array}{c}\text { Sulfur } \\
\text { Avg }\end{array}$ \\
\hline 0 & & & & & 0 \\
\hline 5 & ND & 14 & ND & ND & ND \\
\hline 13 & ND & 15 & ND & ND & 1150 \\
\hline 18 & ND & 18 & ND & ND & \#NA \\
\hline 24 & ND & 18 & 22 & ND & 1595 \\
\hline 28 & ND & 37 & ND & ND & 873 \\
\hline 35 & 161 & 37 & 32 & ND & \#NA \\
\hline 40 & ND & 16 & 10 & ND & 1450 \\
\hline 46 & ND & ND & ND & ND & 7245 \\
\hline 55 & ND & ND & ND & ND & 1910 \\
\hline 106 & & & & & 15500 \\
\hline \multicolumn{6}{|c|}{ P102 } \\
\hline Day & $\begin{array}{c}\text { Aluminum } \\
\text { Avg }\end{array}$ & $\begin{array}{l}\text { Iron } \\
\text { Avg }\end{array}$ & $\begin{array}{c}\text { Magnesium } \\
\text { Avg }\end{array}$ & $\begin{array}{c}\text { Silicon } \\
\text { Avg }\end{array}$ & $\begin{array}{c}\text { Sulfur } \\
\text { Avg }\end{array}$ \\
\hline 0 & & & & & 0 \\
\hline 5 & ND & 14 & ND & ND & ND \\
\hline 13 & ND & 11 & ND & ND & ND \\
\hline 18 & ND & 12 & 21 & ND & ND \\
\hline 24 & ND & ND & ND & ND & ND \\
\hline 28 & ND & ND & ND & ND & 338 \\
\hline 35 & 167 & 30 & 34 & ND & \#NA \\
\hline
\end{tabular}


Table A.2. (contd)

\begin{tabular}{|c|c|c|c|c|c|c|}
\hline Day & $\begin{array}{c}\text { Aluminum } \\
\text { Avg }\end{array}$ & $\begin{array}{l}\text { Iron } \\
\text { Avg }\end{array}$ & $\begin{array}{l}\text { Magnesium } \\
\text { Avg }\end{array}$ & $\begin{array}{l}\text { Silicon } \\
\text { Avg }\end{array}$ & \multicolumn{2}{|l|}{$\begin{array}{c}\text { Sulfur } \\
\text { Avg }\end{array}$} \\
\hline 40 & ND & 11 & 10 & ND & 548 & \\
\hline 46 & ND & & ND & ND & 1370 & \\
\hline 55 & ND & & 11 & ND & 814 & \\
\hline 106 & & & & & \multicolumn{2}{|l|}{1401} \\
\hline \multicolumn{7}{|c|}{ P103 } \\
\hline & Aluminum & Iron & Magnesium & Silicon & \multirow{2}{*}{\multicolumn{2}{|c|}{$\begin{array}{c}\text { Sulfur } \\
\text { Avg }\end{array}$}} \\
\hline Day & Avg & Avg & Avg & Avg & & \\
\hline 0 & & & & & \multicolumn{2}{|l|}{0} \\
\hline 5 & 120000 & 519 & ND & ND & \multicolumn{2}{|l|}{ ND } \\
\hline 13 & 148500 & 621 & ND & ND & \multicolumn{2}{|l|}{ ND } \\
\hline 18 & 107500 & 495 & 11 & ND & \multicolumn{2}{|l|}{ ND } \\
\hline 24 & 135500 & 544 & ND & ND & \multicolumn{2}{|l|}{419} \\
\hline 28 & 121500 & 435 & ND & ND & \multicolumn{2}{|l|}{367} \\
\hline 35 & 113500 & 247 & 29 & ND & \multicolumn{2}{|l|}{ \#NA } \\
\hline 40 & 114000 & 85 & 0 & ND & \multicolumn{2}{|l|}{578} \\
\hline 46 & 113000 & 41 & ND & ND & \multicolumn{2}{|l|}{618} \\
\hline 55 & 113500 & 27 & ND & ND & \multicolumn{2}{|l|}{799} \\
\hline 106 & & & & & \multicolumn{2}{|l|}{1399} \\
\hline \multicolumn{7}{|c|}{ P104 } \\
\hline & Aluminum & Iron & \multirow{2}{*}{$\begin{array}{l}\text { Magnesium } \\
\text { Avg }\end{array}$} & Silicon & \multicolumn{2}{|l|}{ Sulfur } \\
\hline Day & Avg & Avg & & Avg & Avg & $\%$ \\
\hline 0 & & & & & \multicolumn{2}{|l|}{0} \\
\hline 5 & 118500 & 473 & ND & ND & ND & \\
\hline 13 & 157500 & 580 & ND & ND & ND & \\
\hline 18 & 126000 & 490 & ND & ND & ND & \\
\hline 24 & 149500 & 598 & 10 & ND & ND & \\
\hline 28 & 142500 & 574 & ND & ND & ND & \\
\hline 35 & 138500 & 594 & 22 & 177 & ND & \\
\hline 40 & 102500 & 457 & ND & ND & ND & \\
\hline 46 & 113000 & 473 & ND & ND & ND & \\
\hline 55 & 91550 & 373 & 5 & ND & ND & \\
\hline 106 & & & & & & \\
\hline & & & P105 & & & \\
\hline & Aluminum & Iron & Magnesium & Silicon & Sulfur & \\
\hline Day & Avg & Avg & Avg & Avg & Avg & \\
\hline 0 & & & & & 0 & \\
\hline 5 & ND & 12 & ND & ND & 1095 & \\
\hline 13 & ND & 21 & ND & ND & 8625 & \\
\hline 18 & ND & 20 & ND & ND & \#NA & \\
\hline 24 & ND & 18 & ND & ND & 6810 & \\
\hline 28 & ND & 16 & ND & ND & 5320 & \\
\hline 35 & \#NA & \#NA & \#NA & \#NA & \#NA & \\
\hline 40 & ND & 252 & 10 & ND & 14900 & \\
\hline
\end{tabular}


Table A.2. (contd)

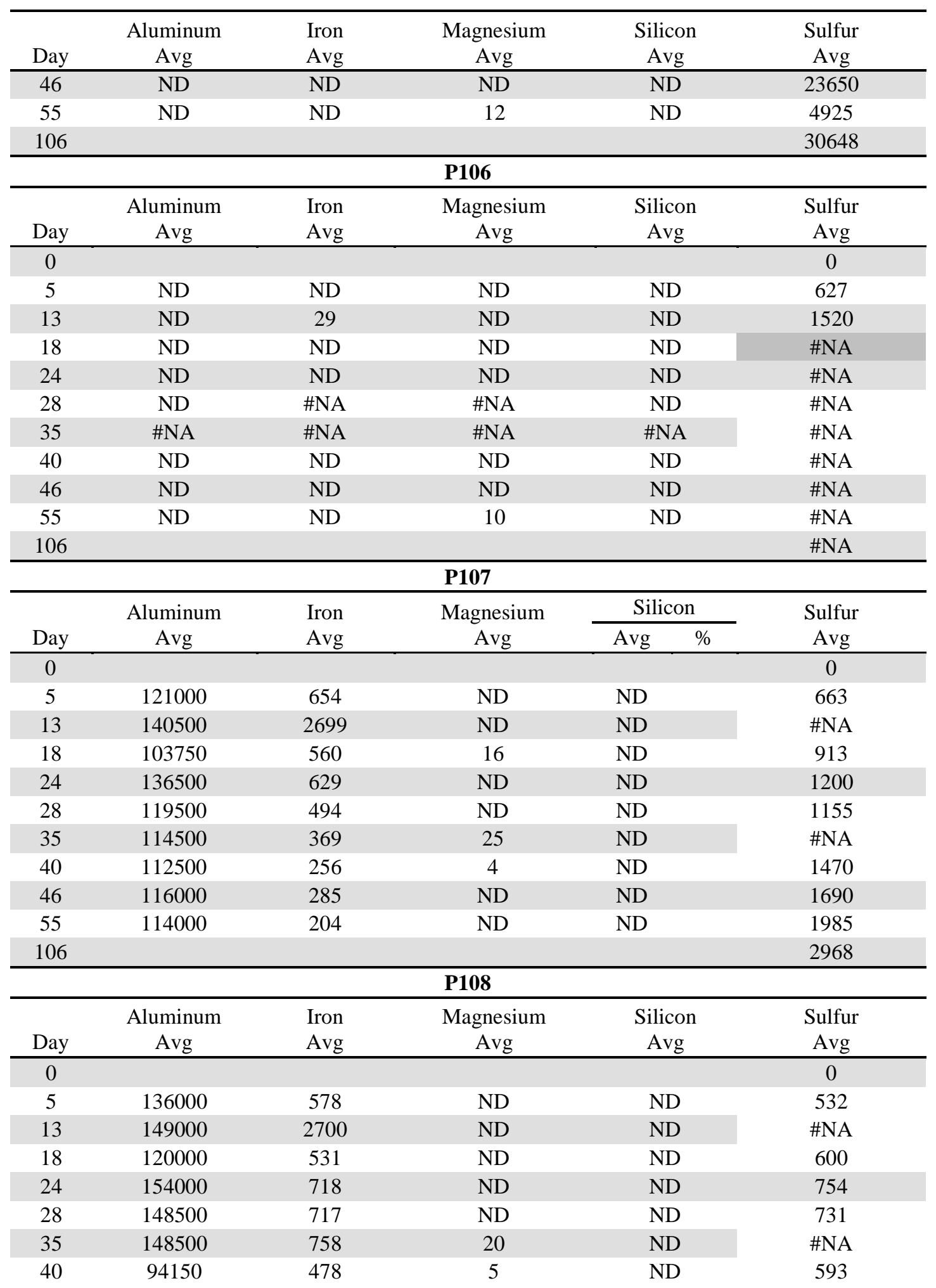


Table A.2. (contd)

\begin{tabular}{|c|c|c|c|c|c|}
\hline Day & $\begin{array}{c}\text { Aluminum } \\
\text { Avg }\end{array}$ & $\begin{array}{l}\text { Iron } \\
\text { Avg }\end{array}$ & $\begin{array}{l}\text { Magnesium } \\
\text { Avg }\end{array}$ & $\begin{array}{c}\text { Silicon } \\
\text { Avg }\end{array}$ & $\begin{array}{c}\text { Sulfur } \\
\text { Avg }\end{array}$ \\
\hline 46 & 116500 & 554 & ND & ND & 697 \\
\hline 55 & 84950 & 411 & ND & ND & 677 \\
\hline 106 & & & & & 1170 \\
\hline \multicolumn{6}{|c|}{ P109 } \\
\hline Day & $\begin{array}{c}\text { Aluminum } \\
\text { Avg }\end{array}$ & $\begin{array}{l}\text { Iron } \\
\text { Avg }\end{array}$ & $\begin{array}{c}\text { Magnesium } \\
\text { Avg }\end{array}$ & $\begin{array}{c}\text { Silicon } \\
\text { Avg }\end{array}$ & $\begin{array}{c}\text { Sulfur } \\
\text { Avg }\end{array}$ \\
\hline 0 & & & & & 0 \\
\hline 5 & 121500 & 496 & ND & ND & ND \\
\hline 13 & 144500 & 507 & ND & ND & ND \\
\hline 18 & 117000 & 208 & ND & ND & ND \\
\hline 24 & 135000 & 106 & ND & ND & ND \\
\hline 28 & 125500 & 50 & ND & ND & ND \\
\hline 35 & 114000 & 73 & 42 & ND & ND \\
\hline 40 & 121000 & 36 & ND & ND & 454 \\
\hline 46 & 118000 & 29 & ND & ND & 523 \\
\hline 55 & 117500 & 327 & ND & ND & 683 \\
\hline 106 & & & & & 1171 \\
\hline \multicolumn{6}{|c|}{ P110 } \\
\hline Day & $\begin{array}{c}\text { Aluminum } \\
\text { Avg }\end{array}$ & $\begin{array}{l}\text { Iron } \\
\text { Avg }\end{array}$ & $\begin{array}{c}\text { Magnesium } \\
\text { Avg }\end{array}$ & $\begin{array}{c}\text { Silicon } \\
\text { Avg }\end{array}$ & $\begin{array}{c}\text { Sulfur } \\
\text { Avg }\end{array}$ \\
\hline 0 & & & & & 0 \\
\hline 5 & 124000 & 1195 & ND & ND & 1275 \\
\hline 13 & 139500 & 500 & ND & ND & 908 \\
\hline 18 & 119000 & 221 & ND & ND & 886 \\
\hline 24 & 122000 & 73 & ND & ND & 908 \\
\hline 28 & 126500 & 61 & 134 & ND & 985 \\
\hline 35 & 115000 & 80 & 35 & 176 & \#NA \\
\hline 40 & 116500 & 46 & ND & ND & 1235 \\
\hline 46 & 119500 & 33 & ND & ND & 1355 \\
\hline 55 & 116500 & 24 & ND & ND & 1625 \\
\hline 106 & & & & & 2632 \\
\hline
\end{tabular}


Table A.2. (contd)

\begin{tabular}{|c|c|c|c|c|c|}
\hline \multicolumn{6}{|c|}{ O1 } \\
\hline Day & $\begin{array}{l}\text { Aluminum } \\
\text { Avg }\end{array}$ & $\begin{array}{l}\text { Iron } \\
\text { Avg }\end{array}$ & $\begin{array}{l}\text { Magnesium } \\
\text { Avg }\end{array}$ & $\begin{array}{l}\text { Silicon } \\
\text { Avg }\end{array}$ & $\begin{array}{c}\text { Sulfur } \\
\text { Avg }\end{array}$ \\
\hline 14 & 118 & 345 & 130 & ND & 3500 \\
\hline 21 & 82 & 14 & 28 & ND & ND \\
\hline 27 & ND & 10 & 58 & ND & ND \\
\hline 36 & ND & 37 & 37 & ND & ND \\
\hline 44 & ND & 10 & 10 & ND & ND \\
\hline 49 & 23 & 7 & 7 & ND & ND \\
\hline 55 & ND & 47 & ND & ND & ND \\
\hline 59 & ND & 15 & 46 & ND & ND \\
\hline \multicolumn{6}{|c|}{$\mathrm{O2}$} \\
\hline Day & $\begin{array}{c}\text { Aluminum } \\
\text { Avg }\end{array}$ & $\begin{array}{l}\text { Iron } \\
\text { Avg }\end{array}$ & $\begin{array}{c}\text { Magnesium } \\
\text { Avg }\end{array}$ & $\begin{array}{l}\text { Silicon } \\
\text { Avg }\end{array}$ & $\begin{array}{c}\text { Sulfur } \\
\text { Avg }\end{array}$ \\
\hline 14 & 75 & 33 & 51 & ND & 1790 \\
\hline 20 & 78 & 24 & 36 & ND & ND \\
\hline 26 & ND & ND & 52 & ND & ND \\
\hline 35 & ND & ND & 46 & ND & ND \\
\hline 43 & ND & 14 & 72 & ND & ND \\
\hline 48 & ND & 38 & ND & ND & ND \\
\hline 54 & ND & 28 & 93 & ND & ND \\
\hline 58 & ND & 17 & 50 & ND & ND \\
\hline \multicolumn{6}{|c|}{$\mathbf{O 3}$} \\
\hline Day & $\begin{array}{c}\text { Aluminum } \\
\text { Avg }\end{array}$ & $\begin{array}{l}\text { Iron } \\
\text { Avg }\end{array}$ & $\begin{array}{l}\text { Magnesium } \\
\text { Avg }\end{array}$ & $\begin{array}{c}\text { Silicon } \\
\text { Avg }\end{array}$ & $\begin{array}{c}\text { Sulfur } \\
\text { Avg }\end{array}$ \\
\hline 4 & 112000 & 146 & 21 & ND & ND \\
\hline 10 & 111000 & 143 & ND & ND & ND \\
\hline 19 & 100650 & 355 & 810 & 849 & ND \\
\hline 27 & 130000 & 155 & ND & ND & ND \\
\hline 32 & 122000 & 157 & 12 & ND & ND \\
\hline 38 & 131500 & 138 & ND & ND & ND \\
\hline 42 & 123000 & 166 & 10 & ND & ND \\
\hline \multicolumn{6}{|c|}{04} \\
\hline Day & $\begin{array}{c}\text { Aluminum } \\
\text { Avg }\end{array}$ & $\begin{array}{l}\text { Iron } \\
\text { Avg }\end{array}$ & $\begin{array}{l}\text { Magnesium } \\
\text { Avg }\end{array}$ & $\begin{array}{c}\text { Silicon } \\
\text { Avg }\end{array}$ & $\begin{array}{c}\text { Sulfur } \\
\text { Avg }\end{array}$ \\
\hline 4 & 116000 & 158 & 13 & ND & ND \\
\hline 10 & 122000 & 163 & ND & ND & ND \\
\hline 19 & 152500 & 173 & ND & ND & ND \\
\hline 27 & 183500 & \#NA & 580 & 335 & ND \\
\hline 32 & 214500 & 202 & ND & ND & ND \\
\hline 38 & 271500 & 186 & ND & ND & ND \\
\hline 42 & 107000 & 139 & 43 & ND & ND \\
\hline
\end{tabular}


Table A.2. (contd)

\begin{tabular}{|c|c|c|c|c|c|}
\hline \multicolumn{6}{|c|}{05} \\
\hline Day & $\begin{array}{l}\text { Aluminum } \\
\text { Avg }\end{array}$ & $\begin{array}{l}\text { Iron } \\
\text { Avg }\end{array}$ & $\begin{array}{l}\text { Magnesium } \\
\text { Avg }\end{array}$ & $\begin{array}{l}\text { Silicon } \\
\text { Avg }\end{array}$ & $\begin{array}{c}\text { Sulfur } \\
\text { Avg }\end{array}$ \\
\hline 5 & ND & ND & ND & ND & ND \\
\hline 14 & ND & 280 & 792 & 860 & ND \\
\hline 22 & ND & 10 & 4 & ND & ND \\
\hline 27 & ND & ND & ND & ND & ND \\
\hline 33 & ND & ND & 25 & ND & ND \\
\hline 37 & ND & 421 & 1128 & 1310 & ND \\
\hline \multicolumn{6}{|c|}{06} \\
\hline & Aluminum & Iron & Magnesium & Silicon & Sulfur \\
\hline Day & Avg & Avg & Avg & Avg & Avg \\
\hline 5 & ND & 736 & 3760 & 2120 & ND \\
\hline 14 & ND & 487 & 2755 & 1568 & ND \\
\hline 22 & ND & 107 & 604 & 342 & ND \\
\hline 27 & ND & ND & 85 & ND & ND \\
\hline 33 & ND & ND & 104 & ND & ND \\
\hline 37 & ND & 65 & 348 & 251 & ND \\
\hline \multicolumn{6}{|c|}{ O7 } \\
\hline Day & $\begin{array}{c}\text { Aluminum } \\
\text { Avg }\end{array}$ & $\begin{array}{l}\text { Iron } \\
\text { Avg }\end{array}$ & $\begin{array}{c}\text { Magnesium } \\
\text { Avg }\end{array}$ & $\begin{array}{l}\text { Silicon } \\
\text { Avg }\end{array}$ & $\begin{array}{r}\text { Sulfur } \\
\text { Avg }\end{array}$ \\
\hline 5 & 113000 & 211 & 304 & 188 & ND \\
\hline 14 & 246000 & 324 & 145 & 192 & ND \\
\hline 22 & 131500 & 616 & 2721 & 1594 & ND \\
\hline 27 & 116000 & 214 & 330 & 224 & ND \\
\hline 33 & 120000 & 180 & 147 & ND & ND \\
\hline 37 & 129000 & 236 & 465 & 279 & ND \\
\hline \multicolumn{6}{|c|}{08} \\
\hline Day & $\begin{array}{c}\text { Aluminum } \\
\text { Avg }\end{array}$ & $\begin{array}{l}\text { Iron } \\
\text { Avg }\end{array}$ & $\begin{array}{c}\text { Magnesium } \\
\text { Avg }\end{array}$ & $\begin{array}{l}\text { Silicon } \\
\text { Avg }\end{array}$ & $\begin{array}{c}\text { Sulfur } \\
\text { Avg }\end{array}$ \\
\hline 5 & 124000 & 353 & 554 & 334 & ND \\
\hline 14 & 151500 & 177 & ND & ND & ND \\
\hline 22 & 188500 & 216 & ND & ND & ND \\
\hline 27 & 219500 & 240 & ND & ND & ND \\
\hline 33 & 272500 & 238 & ND & 167 & ND \\
\hline 37 & 106500 & 121 & 151 & 145 & ND \\
\hline \multicolumn{6}{|c|}{ O9 } \\
\hline Day & $\begin{array}{c}\text { Aluminum } \\
\text { Avg }\end{array}$ & $\begin{array}{l}\text { Iron } \\
\text { Avg } \\
\end{array}$ & $\begin{array}{c}\text { Magnesium } \\
\text { Avg }\end{array}$ & $\begin{array}{c}\text { Silicon } \\
\text { Avg }\end{array}$ & $\begin{array}{r}\text { Sulfur } \\
\text { Avg }\end{array}$ \\
\hline 5 & 115000 & 148 & 3 & ND & ND \\
\hline 14 & 125000 & 108 & ND & ND & ND \\
\hline 22 & 133000 & 172 & 315 & 200 & ND \\
\hline 27 & 117000 & 85 & 10 & ND & ND \\
\hline 33 & 121500 & 71 & ND & ND & ND \\
\hline 37 & 126000 & 600 & 1670 & 1810 & ND \\
\hline
\end{tabular}


Table A.2. (contd)

\begin{tabular}{|c|c|c|c|c|c|}
\hline \multicolumn{6}{|c|}{$\mathbf{O 1 0}$} \\
\hline Day & $\begin{array}{l}\text { Aluminum } \\
\text { Avg }\end{array}$ & $\begin{array}{l}\text { Iron } \\
\text { Avg }\end{array}$ & $\begin{array}{l}\text { Magnesium } \\
\text { Avg }\end{array}$ & $\begin{array}{l}\text { Silicon } \\
\text { Avg }\end{array}$ & $\begin{array}{c}\text { Sulfur } \\
\text { Avg }\end{array}$ \\
\hline 5 & 115000 & 145 & 47 & ND & ND \\
\hline 14 & 122000 & 257 & 583 & 380 & ND \\
\hline 22 & 135000 & 117 & 15 & ND & ND \\
\hline 27 & 123000 & 109 & ND & ND & ND \\
\hline 33 & 128000 & 109 & 17 & ND & ND \\
\hline 37 & 137000 & 156 & 247 & 240 & ND \\
\hline \multicolumn{6}{|c|}{0101} \\
\hline Day & $\begin{array}{l}\text { Aluminum } \\
\text { Avg }\end{array}$ & $\begin{array}{l}\text { Iron } \\
\text { Avg }\end{array}$ & $\begin{array}{l}\text { Magnesium } \\
\text { Avg }\end{array}$ & $\begin{array}{l}\text { Silicon } \\
\text { Avg }\end{array}$ & $\begin{array}{c}\text { Sulfur } \\
\text { Avg }\end{array}$ \\
\hline 5 & ND & ND & 17 & ND & ND \\
\hline 13 & 20 & ND & 9 & ND & ND \\
\hline 18 & ND & 14 & 21 & ND & ND \\
\hline 24 & ND & ND & ND & ND & ND \\
\hline 28 & ND & ND & ND & ND & ND \\
\hline \multicolumn{6}{|c|}{0102} \\
\hline Day & $\begin{array}{c}\text { Aluminum } \\
\text { Avg }\end{array}$ & $\begin{array}{l}\text { Iron } \\
\text { Avg }\end{array}$ & $\begin{array}{c}\text { Magnesium } \\
\text { Avg }\end{array}$ & $\begin{array}{c}\text { Silicon } \\
\text { Avg }\end{array}$ & $\begin{array}{c}\text { Sulfur } \\
\text { Avg }\end{array}$ \\
\hline 5 & ND & ND & 4 & ND & ND \\
\hline 13 & ND & ND & ND & ND & ND \\
\hline 18 & ND & ND & ND & ND & ND \\
\hline 24 & ND & ND & ND & ND & ND \\
\hline 28 & ND & ND & 15 & ND & ND \\
\hline \multicolumn{6}{|c|}{0103} \\
\hline Day & $\begin{array}{l}\text { Aluminum } \\
\text { Avg }\end{array}$ & $\begin{array}{l}\text { Iron } \\
\text { Avg }\end{array}$ & $\begin{array}{l}\text { Magnesium } \\
\text { Avg }\end{array}$ & $\begin{array}{l}\text { Silicon } \\
\text { Avg }\end{array}$ & $\begin{array}{c}\text { Sulfur } \\
\text { Avg }\end{array}$ \\
\hline 5 & 122000 & 465 & 17 & ND & ND \\
\hline 13 & 143000 & 496 & ND & ND & ND \\
\hline 18 & 126000 & 470 & ND & ND & ND \\
\hline 24 & 125500 & 457 & ND & ND & ND \\
\hline 28 & 123500 & 448 & ND & ND & ND \\
\hline \multicolumn{6}{|c|}{0104} \\
\hline Day & $\begin{array}{c}\text { Aluminum } \\
\text { Avg }\end{array}$ & $\begin{array}{l}\text { Iron } \\
\text { Avg }\end{array}$ & $\begin{array}{c}\text { Magnesium } \\
\text { Avg }\end{array}$ & $\begin{array}{c}\text { Silicon } \\
\text { Avg }\end{array}$ & $\begin{array}{c}\text { Sulfur } \\
\text { Avg }\end{array}$ \\
\hline 5 & 124500 & 469 & ND & ND & ND \\
\hline 13 & 162000 & 547 & ND & ND & ND \\
\hline 18 & 132500 & 491 & ND & ND & ND \\
\hline 24 & 158500 & 559 & ND & ND & ND \\
\hline 28 & 147500 & 563 & ND & ND & ND \\
\hline
\end{tabular}


Table A.2. (contd)

\begin{tabular}{|c|c|c|c|c|c|}
\hline \multicolumn{6}{|c|}{0105} \\
\hline Day & $\begin{array}{l}\text { Aluminum } \\
\text { Avg }\end{array}$ & $\begin{array}{l}\text { Iron } \\
\text { Avg }\end{array}$ & $\begin{array}{c}\text { Magnesium } \\
\text { Avg }\end{array}$ & $\begin{array}{l}\text { Silicon } \\
\text { Avg }\end{array}$ & $\begin{array}{c}\text { Sulfur } \\
\text { Avg }\end{array}$ \\
\hline 5 & ND & ND & 15 & ND & ND \\
\hline 13 & ND & ND & ND & ND & ND \\
\hline 18 & 20 & ND & ND & ND & ND \\
\hline 24 & ND & ND & ND & ND & ND \\
\hline 28 & 149 & 23 & 34 & ND & ND \\
\hline \multicolumn{6}{|c|}{0106} \\
\hline Day & $\begin{array}{c}\text { Aluminum } \\
\text { Avg }\end{array}$ & $\begin{array}{l}\text { Iron } \\
\text { Avg }\end{array}$ & $\begin{array}{c}\text { Magnesium } \\
\text { Avg }\end{array}$ & $\begin{array}{c}\text { Silicon } \\
\text { Avg }\end{array}$ & $\begin{array}{c}\text { Sulfur } \\
\text { Avg }\end{array}$ \\
\hline 5 & ND & ND & 14 & ND & ND \\
\hline 13 & ND & \#NA & \#NA & \#NA & ND \\
\hline 18 & ND & ND & ND & ND & ND \\
\hline 24 & ND & 30 & 13 & ND & ND \\
\hline 28 & ND & ND & ND & ND & ND \\
\hline \multicolumn{6}{|c|}{0107} \\
\hline Day & $\begin{array}{c}\text { Aluminum } \\
\text { Avg }\end{array}$ & $\begin{array}{l}\text { Iron } \\
\text { Avg }\end{array}$ & $\begin{array}{c}\text { Magnesium } \\
\text { Avg }\end{array}$ & $\begin{array}{c}\text { Silicon } \\
\text { Avg }\end{array}$ & $\begin{array}{r}\text { Sulfur } \\
\text { Avg }\end{array}$ \\
\hline 5 & 120000 & 466 & 68 & ND & ND \\
\hline 13 & 148500 & 534 & 47 & ND & ND \\
\hline 18 & 116500 & 426 & 44 & ND & ND \\
\hline 24 & 135000 & 474 & 33 & ND & ND \\
\hline 28 & 121500 & 451 & 83 & ND & ND \\
\hline \multicolumn{6}{|c|}{0108} \\
\hline Day & $\begin{array}{l}\text { Aluminum } \\
\text { Avg }\end{array}$ & $\begin{array}{l}\text { Iron } \\
\text { Avg }\end{array}$ & $\begin{array}{l}\text { Magnesium } \\
\text { Avg }\end{array}$ & $\begin{array}{l}\text { Silicon } \\
\text { Avg }\end{array}$ & $\begin{array}{c}\text { Sulfur } \\
\text { Avg }\end{array}$ \\
\hline 5 & 134000 & 499 & 6 & ND & ND \\
\hline 13 & 164500 & 574 & ND & ND & ND \\
\hline 18 & 141500 & 504 & ND & ND & ND \\
\hline 24 & 166500 & 583 & ND & ND & ND \\
\hline 28 & 152500 & 554 & ND & ND & ND \\
\hline \multicolumn{6}{|c|}{0109} \\
\hline Day & $\begin{array}{c}\text { Aluminum } \\
\text { Avg }\end{array}$ & $\begin{array}{l}\text { Iron } \\
\text { Avg }\end{array}$ & $\begin{array}{c}\text { Magnesium } \\
\text { Avg }\end{array}$ & $\begin{array}{c}\text { Silicon } \\
\text { Avg }\end{array}$ & $\begin{array}{r}\text { Sulfur } \\
\text { Avg }\end{array}$ \\
\hline 5 & 127500 & 469 & 4 & ND & ND \\
\hline 13 & 136500 & 453 & ND & ND & ND \\
\hline 18 & 118000 & 400 & ND & ND & ND \\
\hline 24 & 127500 & 388 & ND & ND & ND \\
\hline 28 & 126500 & 404 & ND & ND & ND \\
\hline
\end{tabular}


Table A.2. (contd)

\begin{tabular}{|c|c|c|c|c|c|}
\hline \multicolumn{6}{|c|}{0110} \\
\hline Day & $\begin{array}{c}\text { Aluminum } \\
\text { Avg }\end{array}$ & $\begin{array}{l}\text { Iron } \\
\text { Avg }\end{array}$ & $\begin{array}{c}\text { Magnesium } \\
\text { Avg }\end{array}$ & $\begin{array}{l}\text { Silicon } \\
\text { Avg }\end{array}$ & $\begin{array}{c}\text { Sulfur } \\
\text { Avg }\end{array}$ \\
\hline 5 & 119500 & 419 & 5 & 159 & ND \\
\hline 13 & 135000 & 434 & ND & 189 & ND \\
\hline 18 & 109500 & 321 & ND & 171 & ND \\
\hline 24 & 134000 & 336 & ND & ND & ND \\
\hline 28 & 128000 & 305 & ND & ND & ND \\
\hline
\end{tabular}

A.13 
Table A.2. (contd)

\begin{tabular}{|c|c|c|c|c|c|}
\hline \multicolumn{6}{|c|}{ G1 } \\
\hline Day & $\begin{array}{c}\text { Aluminum } \\
\text { Avg }\end{array}$ & $\begin{array}{l}\text { Iron } \\
\text { Avg }\end{array}$ & $\begin{array}{c}\text { Magnesium } \\
\text { Avg }\end{array}$ & $\begin{array}{l}\text { Silicon } \\
\text { Avg }\end{array}$ & $\begin{array}{c}\text { Sulfur } \\
\text { Avg }\end{array}$ \\
\hline 14 & 88 & 154 & 60 & ND & ND \\
\hline 21 & 105 & 15 & 19 & ND & ND \\
\hline 27 & 17 & 10 & ND & ND & ND \\
\hline 36 & 17 & 13 & 8 & ND & ND \\
\hline 44 & ND & 28 & ND & ND & ND \\
\hline 49 & ND & ND & ND & ND & ND \\
\hline 55 & ND & ND & ND & ND & ND \\
\hline 59 & ND & ND & ND & ND & ND \\
\hline \multicolumn{6}{|c|}{ G2 } \\
\hline Day & $\begin{array}{c}\text { Aluminum } \\
\text { Avg }\end{array}$ & $\begin{array}{l}\text { Iron } \\
\text { Avg }\end{array}$ & $\begin{array}{l}\text { Magnesium } \\
\text { Avg }\end{array}$ & $\begin{array}{c}\text { Silicon } \\
\text { Avg }\end{array}$ & $\begin{array}{c}\text { Sulfur } \\
\text { Avg }\end{array}$ \\
\hline 14 & 108 & 44 & 23 & ND & ND \\
\hline 20 & 102 & 15 & 18 & ND & ND \\
\hline 26 & 18 & 13 & 14 & ND & ND \\
\hline 35 & 18 & 10 & 4 & ND & ND \\
\hline 43 & 40 & 49 & 18 & ND & ND \\
\hline 48 & 25 & 20 & ND & ND & ND \\
\hline \multirow[t]{2}{*}{54} & 17 & ND & ND & ND & ND \\
\hline & 17 & 17 & ND & ND & ND \\
\hline \multicolumn{6}{|c|}{ G3 } \\
\hline Day & $\begin{array}{c}\text { Aluminum } \\
\text { Avg }\end{array}$ & $\begin{array}{l}\text { Iron } \\
\text { Avg }\end{array}$ & $\begin{array}{l}\text { Magnesium } \\
\text { Avg }\end{array}$ & $\begin{array}{c}\text { Silicon } \\
\text { Avg }\end{array}$ & $\begin{array}{c}\text { Sulfur } \\
\text { Avg }\end{array}$ \\
\hline 4 & 113000 & 145 & 14 & ND & ND \\
\hline 10 & 106000 & 189 & ND & ND & ND \\
\hline 19 & 117500 & 159 & ND & ND & ND \\
\hline 27 & 127000 & 197 & ND & ND & ND \\
\hline 32 & 118500 & 149 & ND & ND & ND \\
\hline 38 & 124500 & 140 & 11 & ND & ND \\
\hline 42 & 127000 & 219 & 12 & ND & ND \\
\hline \multicolumn{6}{|c|}{ G4 } \\
\hline Day & $\begin{array}{c}\text { Aluminum } \\
\text { Avg }\end{array}$ & $\begin{array}{l}\text { Iron } \\
\text { Avg }\end{array}$ & $\begin{array}{c}\text { Magnesium } \\
\text { Avg }\end{array}$ & $\begin{array}{c}\text { Silicon } \\
\text { Avg }\end{array}$ & $\begin{array}{c}\text { Sulfur } \\
\text { Avg }\end{array}$ \\
\hline 4 & 114000 & 220 & 13 & ND & ND \\
\hline 10 & 124000 & 199 & ND & ND & ND \\
\hline 19 & 143000 & 162 & ND & ND & ND \\
\hline 27 & 171500 & 265 & ND & ND & ND \\
\hline 32 & 162500 & 164 & ND & ND & ND \\
\hline 38 & 230500 & 163 & ND & ND & ND \\
\hline 42 & 137000 & 124 & ND & ND & ND \\
\hline
\end{tabular}


Table A.2. (contd)

\begin{tabular}{|c|c|c|c|c|c|}
\hline \multicolumn{6}{|c|}{ G5 } \\
\hline & Aluminum & Iron & Magnesium & Silicon & Sulfur \\
\hline Day & Avg & Avg & Avg & Avg & Avg \\
\hline 5 & 91 & ND & ND & ND & ND \\
\hline 14 & 119 & 11 & 8 & 145 & ND \\
\hline 22 & 308 & 438 & 156 & 802 & ND \\
\hline 27 & 121 & ND & ND & 135 & ND \\
\hline 33 & 128 & ND & ND & 140 & ND \\
\hline 37 & 127 & 11 & 3 & 138 & ND \\
\hline \multicolumn{6}{|c|}{ G6 } \\
\hline & Aluminum & Iron & Magnesium & Silicon & Sulfur \\
\hline Day & Avg & Avg & Avg & Avg & Avg \\
\hline 5 & 94 & 12 & 6 & ND & ND \\
\hline 14 & 148 & 106 & 40 & 199 & ND \\
\hline 22 & 117 & 178 & 57 & 225 & ND \\
\hline 27 & 51 & 42 & 11 & ND & ND \\
\hline \multirow[t]{2}{*}{33} & 52 & 30 & 19 & ND & ND \\
\hline & 38 & 23 & 13 & 164 & ND \\
\hline \multicolumn{6}{|c|}{ G7 } \\
\hline & Aluminum & Iron & Magnesium & Silicon & Sulfur \\
\hline Day & Avg & Avg & Avg & Avg & Avg \\
\hline 5 & 115000 & 562 & 94 & 287 & ND \\
\hline 16 & 239000 & 516 & ND & 327 & ND \\
\hline 22 & 126000 & 272 & ND & 154 & ND \\
\hline 27 & 117000 & 258 & ND & 163 & ND \\
\hline 33 & 121500 & 208 & 20 & 164 & ND \\
\hline 37 & 120000 & 163 & ND & 157 & ND \\
\hline \multicolumn{6}{|c|}{ G8 } \\
\hline & Aluminum & Iron & Magnesium & Silicon & Sulfur \\
\hline Day & Avg & Avg & Avg & Avg & Avg \\
\hline 5 & 123000 & 572 & 88 & 273 & ND \\
\hline 14 & 147500 & 261 & ND & 169 & ND \\
\hline 22 & 159500 & 296 & 23 & 215 & ND \\
\hline 27 & 202000 & 194 & ND & 261 & ND \\
\hline 33 & 258500 & 164 & ND & 347 & ND \\
\hline 37 & 119000 & 79 & ND & 160 & ND \\
\hline \multicolumn{6}{|c|}{ G9 } \\
\hline & Aluminum & Iron & Magnesium & Silicon & Sulfur \\
\hline Day & Avg & Avg & Avg & Avg & Avg \\
\hline 5 & 112000 & 134 & ND & ND & ND \\
\hline 14 & 117000 & 99 & ND & ND & ND \\
\hline 22 & 133500 & 222 & 5 & ND & ND \\
\hline 27 & 120500 & 88 & ND & ND & ND \\
\hline 33 & 123000 & 78 & ND & ND & ND \\
\hline 37 & 131000 & 131 & ND & ND & ND \\
\hline
\end{tabular}


Table A.2. (contd)

\begin{tabular}{|c|c|c|c|c|c|}
\hline \multicolumn{6}{|c|}{ G10 } \\
\hline Day & $\begin{array}{l}\text { Aluminum } \\
\text { Avg }\end{array}$ & $\begin{array}{l}\text { Iron } \\
\text { Avg }\end{array}$ & $\begin{array}{l}\text { Magnesium } \\
\text { Avg }\end{array}$ & $\begin{array}{l}\text { Silicon } \\
\text { Avg }\end{array}$ & $\begin{array}{c}\text { Sulfur } \\
\text { Avg }\end{array}$ \\
\hline 5 & 132000 & 419 & 48 & 258 & ND \\
\hline 14 & 128500 & 267 & 28 & 251 & ND \\
\hline 22 & 101000 & 78 & ND & 200 & ND \\
\hline 27 & 108000 & 72 & 8 & 186 & ND \\
\hline 33 & 126000 & 76 & ND & 216 & ND \\
\hline 37 & 135000 & 158 & 30 & 246 & ND \\
\hline \multicolumn{6}{|c|}{ G101 } \\
\hline Day & $\begin{array}{l}\text { Aluminum } \\
\text { Avg }\end{array}$ & $\begin{array}{l}\text { Iron } \\
\text { Avg }\end{array}$ & $\begin{array}{l}\text { Magnesium } \\
\text { Avg }\end{array}$ & $\begin{array}{l}\text { Silicon } \\
\text { Avg }\end{array}$ & $\begin{array}{c}\text { Sulfur } \\
\text { Avg }\end{array}$ \\
\hline 5 & ND & $\mathrm{ND}$ & ND & ND & ND \\
\hline 13 & 22 & ND & ND & ND & ND \\
\hline 18 & 27 & ND & ND & ND & ND \\
\hline 24 & 31 & ND & ND & ND & ND \\
\hline 28 & 33 & 43 & ND & ND & ND \\
\hline \multicolumn{6}{|c|}{ G102 } \\
\hline Day & $\begin{array}{c}\text { Aluminum } \\
\text { Avg }\end{array}$ & $\begin{array}{l}\text { Iron } \\
\text { Avg }\end{array}$ & $\begin{array}{l}\text { Magnesium } \\
\text { Avg }\end{array}$ & $\begin{array}{c}\text { Silicon } \\
\text { Avg }\end{array}$ & $\begin{array}{r}\text { Sulfur } \\
\text { Avg }\end{array}$ \\
\hline 5 & ND & ND & ND & ND & ND \\
\hline 13 & 17 & 14 & ND & ND & ND \\
\hline 18 & 25 & \#NA & ND & ND & ND \\
\hline 24 & 25 & ND & ND & ND & ND \\
\hline 28 & 97 & 25 & 32 & ND & ND \\
\hline \multicolumn{6}{|c|}{ G103 } \\
\hline Day & $\begin{array}{l}\text { Aluminum } \\
\text { Avg }\end{array}$ & $\begin{array}{l}\text { Iron } \\
\text { Avg }\end{array}$ & $\begin{array}{l}\text { Magnesium } \\
\text { Avg }\end{array}$ & $\begin{array}{l}\text { Silicon } \\
\text { Avg }\end{array}$ & $\begin{array}{c}\text { Sulfur } \\
\text { Avg }\end{array}$ \\
\hline 5 & 120000 & 471 & ND & ND & ND \\
\hline 13 & 140500 & 496 & ND & ND & ND \\
\hline 18 & 108500 & 403 & ND & ND & ND \\
\hline 24 & 135500 & 477 & ND & ND & ND \\
\hline 28 & 121500 & 442 & ND & ND & ND \\
\hline \multicolumn{6}{|c|}{ G104 } \\
\hline Day & $\begin{array}{c}\text { Aluminum } \\
\text { Avg }\end{array}$ & $\begin{array}{l}\text { Iron } \\
\text { Avg }\end{array}$ & $\begin{array}{l}\text { Magnesium } \\
\text { Avg }\end{array}$ & $\begin{array}{c}\text { Silicon } \\
\text { Avg }\end{array}$ & $\begin{array}{c}\text { Sulfur } \\
\text { Avg }\end{array}$ \\
\hline 5 & 133500 & 508 & 7 & ND & ND \\
\hline 13 & 162000 & 549 & ND & ND & ND \\
\hline 18 & 110500 & 409 & ND & ND & ND \\
\hline 24 & 160500 & 616 & ND & ND & ND \\
\hline 28 & 154000 & 581 & 26 & ND & ND \\
\hline
\end{tabular}


Table A.2. (contd)

\begin{tabular}{|c|c|c|c|c|c|}
\hline \multicolumn{6}{|c|}{ G105 } \\
\hline Day & $\begin{array}{l}\text { Aluminum } \\
\text { Avg }\end{array}$ & $\begin{array}{l}\text { Iron } \\
\text { Avg }\end{array}$ & $\begin{array}{l}\text { Magnesium } \\
\text { Avg }\end{array}$ & $\begin{array}{l}\text { Silicon } \\
\text { Avg }\end{array}$ & $\begin{array}{c}\text { Sulfur } \\
\text { Avg }\end{array}$ \\
\hline 5 & 110 & 10 & ND & 142 & ND \\
\hline 13 & 128 & ND & ND & 145 & ND \\
\hline 18 & 134 & ND & 23 & 153 & ND \\
\hline 24 & 154 & $\mathrm{ND}$ & ND & 170 & ND \\
\hline 28 & 140 & 19 & ND & 160 & ND \\
\hline \multicolumn{6}{|c|}{ G106 } \\
\hline Day & $\begin{array}{l}\text { Aluminum } \\
\text { Avg }\end{array}$ & $\begin{array}{l}\text { Iron } \\
\text { Avg }\end{array}$ & $\begin{array}{l}\text { Magnesium } \\
\text { Avg }\end{array}$ & $\begin{array}{l}\text { Silicon } \\
\text { Avg }\end{array}$ & $\begin{array}{c}\text { Sulfur } \\
\text { Avg }\end{array}$ \\
\hline 5 & 102 & 11 & ND & 133 & ND \\
\hline 13 & 127 & ND & ND & 149 & ND \\
\hline 18 & 135 & ND & ND & 156 & ND \\
\hline 24 & 140 & ND & ND & 155 & ND \\
\hline 28 & 137 & 17 & ND & 148 & ND \\
\hline \multicolumn{6}{|c|}{ G107 } \\
\hline Day & $\begin{array}{c}\text { Aluminum } \\
\text { Avg }\end{array}$ & $\begin{array}{l}\text { Iron } \\
\text { Avg }\end{array}$ & $\begin{array}{l}\text { Magnesium } \\
\text { Avg }\end{array}$ & $\begin{array}{c}\text { Silicon } \\
\text { Avg }\end{array}$ & $\begin{array}{c}\text { Sulfur } \\
\text { Avg }\end{array}$ \\
\hline 5 & 123500 & 542 & ND & ND & ND \\
\hline 13 & 148500 & 631 & ND & 155 & ND \\
\hline 18 & 119000 & 529 & ND & ND & ND \\
\hline 24 & 140000 & 629 & ND & 149 & ND \\
\hline 28 & 119000 & 508 & ND & ND & ND \\
\hline \multicolumn{6}{|c|}{ G108 } \\
\hline Day & $\begin{array}{l}\text { Aluminum } \\
\text { Avg }\end{array}$ & $\begin{array}{l}\text { Iron } \\
\text { Avg }\end{array}$ & $\begin{array}{l}\text { Magnesium } \\
\text { Avg }\end{array}$ & $\begin{array}{l}\text { Silicon } \\
\text { Avg }\end{array}$ & $\begin{array}{c}\text { Sulfur } \\
\text { Avg }\end{array}$ \\
\hline 5 & 128500 & 531 & ND & ND & ND \\
\hline 13 & 158000 & 744 & 36 & 208 & ND \\
\hline 18 & 130000 & 526 & ND & ND & ND \\
\hline 24 & 159500 & 640 & ND & 167 & ND \\
\hline 28 & 155000 & 632 & ND & 160 & ND \\
\hline \multicolumn{6}{|c|}{ G109 } \\
\hline Day & $\begin{array}{c}\text { Aluminum } \\
\text { Avg }\end{array}$ & $\begin{array}{l}\text { Iron } \\
\text { Avg }\end{array}$ & $\begin{array}{l}\text { Magnesium } \\
\text { Avg }\end{array}$ & $\begin{array}{c}\text { Silicon } \\
\text { Avg }\end{array}$ & $\begin{array}{c}\text { Sulfur } \\
\text { Avg }\end{array}$ \\
\hline 5 & 118000 & 438 & $\mathrm{ND}$ & ND & ND \\
\hline 13 & 145000 & 497 & ND & ND & ND \\
\hline 18 & 122500 & 424 & 8 & ND & ND \\
\hline 24 & 126000 & 390 & ND & ND & ND \\
\hline 28 & 123500 & 674 & ND & ND & ND \\
\hline
\end{tabular}


Table A.2. (contd)

\begin{tabular}{cccccc}
\hline & & \multicolumn{3}{c}{ G110 } & \\
\hline Day & Aluminum & Iron & Magnesium & Silicon & Sulfur \\
Avg & Avg & Avg & Avg \\
\hline 5 & 121000 & 491 & ND & 159 & ND \\
13 & 141500 & 476 & ND & 189 & ND \\
18 & 114000 & 289 & ND & 171 & ND \\
24 & 129000 & 130 & ND & 202 & ND \\
28 & 126500 & 93 & ND & 187 & ND \\
\hline
\end{tabular}

(a) Eliminated due to serial dilution failure.

ND $=$ not detected

$\mathrm{NA}=$ Eliminated data (experimental error). 



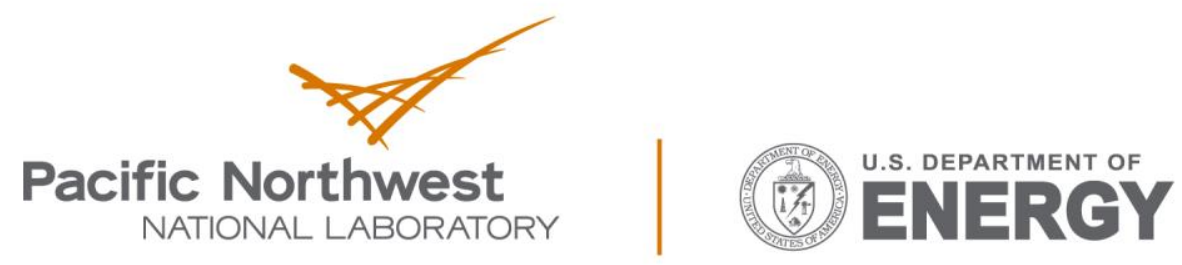

Proudly Operated by Battelle Since 1965

902 Battelle Boulevard

P.O. Box 999

Richland, WA 99352

1-888-375-PNNL (7665)

www.pnnl.gov 